\title{
17. Türkiye Türkçesi atasözlerinde ağaç
}

Ayşe ŞEKER ${ }^{1}$

APA: Şeker, A. (2021). Türkiye Türkçesi atasözlerinde ağaç. RumeliDE Dil ve Edebiyat Araştırmaları Dergisi, (24), 342-363. DOI: 10.29000/rumelide.997526.

$\ddot{\mathbf{O} z}$

Toplumların uzun yıllara dayalı gözlem ve tecrübeleri sonucu ortaya çıkıp günümüze kadar ulaşan atasözleri, ait oldukları milletin ortak duygu, düşünce, gelenek ve inançlarını yansıtır. Her toplumun kendine has atasözleri vardır. Bu atasözlerinde gündelik hayatın bir parçası olan, sosyal hayatta sürekli karşımıza çıkan kavramlar görülmektedir. Bunlardan biri de Türk kültüründe önemli bir yeri olan ağaçtır. Doğudan batıya pek çok kültür ve inanç sisteminde ağaç kavramına bazı sembolik anlamlar yüklenmiştir. İnsanoğlu küçük bir filizken zaman içerisinde büyüyüp gelişen ve sonunda kuruyan ağaç ile kendi hayatı arasında benzerlik kurmuş ve ağaca önem vermiştir. Türkler ağacı kutsal saymış ve ona zarar vermekten imtina etmiştir. Ağaç, edebiyatımızın sözlü ve yazılı bütün ürünlerinde önemli bir tabiat unsuru olarak karşımıza çıkar. Anonim halk edebiyatı ürünlerinden olan atasözlerinde de ağaçla ilgili olanlar ve içerisinde ağaç kavramının geçtiği örnekler sayıca fazladır. Çalışmamızda, atasözlerinde geçen ağaç türleri ele alınacak ve ayrı başlıklar hâlinde incelenecektir. Ağacın çeşitli özellikleri, dilimiz ve kültürümüzdeki yeri, ona verilen simgesel anlamlar çerçevesinde bu türlerin gerçekten mecaza uzanan anlamları üzerinde durulacaktır.

Anahtar kelimeler: Türkiye Türkçesi atasözleri, ağaç, ağaç türleri, Türk kültürü

\section{Tree in Turkish proverbs}

\begin{abstract}
Proverbs, which have emerged as a result of many years of observations and experiences of societies and have survived from past to present, reflect the common feelings, thoughts, traditions and beliefs of the nation to which they belong. Every society has its own proverbs. In these proverbs, certain concepts that are part of everyday life and that constantly appear in social life are observed. One of them is tree, which has an important place in Turkish culture. In many cultures and belief systems from East to West, the concept of tree has symbolic meanings. People have established similarities between themselves and trees, which are small sprouts at first, then grow and develop over time and eventually decay, and have attached importance to the tree. Turkish people have considered trees sacred and have avoided harming them. Tree appears as an important element of nature in all oral and written products of our literature. Amongst proverbs, which are the products of anonymous folk literature, there are the ones related to trees and also the examples in which the concept of tree is mentioned are high in number. In our study, the species of trees mentioned in proverbs will be discussed and will be examined in separate headings. It will focus on the various features of the tree, its place in our language and culture, and the meanings of these species that really extend to the metaphor within the framework of the symbolic meanings given to it.
\end{abstract}

Arş. Gör. Dr., Kırklareli Üniversitesi, Türk Dili ve Edebiyatı Bölümü, Eski Türk Dili ABD (Kırklareli, Türkiye), ayseker87@gmail.com, ORCID ID: oooo-0002-7612-7265 [Araştırma makalesi, Makale kayıt tarihi: 03.09.2021-kabul tarihi: 20.09.2021; DOI: 10.2900o/rumelide.997526

Adres

RumeliDE Dil ve Edebiyat Araşturmaları Dergisi Osmanağa Mahallesi, Mürver Çiçeği Sokak, No:14/8 Kadıköy - ISTANBUL / TÜRKIYE 34714 e-posta: editor@rumelide.com tel: +90 $5057958124,+902167730616$
Address

RumeliDE Journal of Language and Literature Studies

Osmanağa Mahallesi, Mürver Çiçeği Sokak, No:14/8

Kadıköy - ISTANBUL / TURKEY 34714

e-mail: editor@rumelide.com

phone: +90 505 7958124, +90 2167730616 
Keywords: Turkish proverbs, tree, tree species, Turkish culture

\section{Giriş}

Türk dili ve kültüründe önemli bir yer tutan atasözleri için geçmişten günümüze pek çok tanım yapılmıştır. Şinâsi, Durûb-ı Emsâl-i Osmâniyye adlı eserinin ön sözünde atasözleri ile ilgili "durûb-ı emsâl ki hikmetü'l-âvâmdır, lisânından sâdır olduğu bir milletin mâhiyyet-i efkârına delâlet eder" değerlendirmesinde bulunur (H. 1302: 4). Aksoy, atasözlerini "atalarımızın, uzun denemelere dayanan yargılarını genel kural, bilgece düşünce ya da öğüt olarak düsturlaştıran ve kalıplaşmış biçimleri bulunan kamuca benimsenmiş özsözler” şeklinde tanımlar (2020: 35). Türkçe Sözlük’te atasözü, “uzun deneme ve gözlemlere dayanılarak söylenmiş ve halka mal olmuş, öğüt verici nitelikte söz, deme, mesel, sav, darbımesel" olarak verilir (TDK, 2019: 180).

Türk atasözlerinin yazıya geçirilmiş ilk örneklerine Orhun yazıtlarında rastlarız. Ahmet Caferoğlu, Orhun yazıtlarında atasözü niteliği taşıyan üç söz tespit etmiştir (1930: 43-46). Uygur metinlerinde de atasözü örneklerini görürüz. Arat, Berlin Turfan yazmaları arasında bulunan bir tıp kitabının boş sayfalarında "yime Türk savında bar" başlı̆̆ altında sıralanan 14 atasözünden bahseder (1991: 272275). Karahanlı döneminin önemli eserlerinden Kutadgu Bilig, Dîvânu Lugâti’t-Türk ve Atebetü'lHakâyık ile Eski Anadolu Türkçesi dil yadigârlarından olan Dede Korkut Hikâyeleri atasözleri bakımından zengin kaynaklardır. Dîvânu Lugâti't-Türk’te atasözü anlamında saw kelimesi geçmekte olup sawda mundag kelir "atasözünde böyle geçer" denilmektedir (Ercilasun, Akkoyunlu, 2015: 410). Orhun yazıtlarında "söz, haber, mesaj" anlamlarında sab şeklinde karşımıza çıkan kelime Uygurcadan itibaren çift dudak /v/si ile yazılmaya başlanmış olup "söz, haber, ün, atasözü" gibi anlamlarda kullanılmıştır (Şirin, 2015: 41, 42). Kutadgu Bilig'de saw "söz, haber, öğüt, nasihat" manalarında karşımıza çıkarken atasözü anlamında Arapça mesel kelimesi geçmektedir (Arat, 1979: 314, 384). Osmanlı Türkçesinde atasözü için mesel, darb-ı mesel ve onların çoğulu emsâl, durûb-ı emsâl terimleri kullanılmış, XX. yüzyıl başlarından itibaren yerlerini atalar sözü ve atasözü kavramlarına bırakmıştır. Çağdaş Türk lehçelerinde atasözü için Azr. atalar sözü, Bşk. mäkäl, äytim, atalar hüzi, Kzk. makal, mätel, nakıl, Krg. makal-lakap, Özb. makàl, Tat. atalar süzi, mäkal', äytim, Tkm. atalar sözi, nakıl, YUyg. makal kelimeleri kullanılmaktadır (Ercilasun vd., 1991: 32, 33).

Toplumların uzun yıllara dayalı gözlem ve deneyimleri sonucu ortaya çıkıp nesilden nesile aktarılarak günümüze kadar ulaşan atasözleri, ait oldukları toplumların ortak duygu, düşünce, gelenek ve inançlarını yansıtır. Pek çok kelime ile anlatılabilecek durumlar atasözleri yoluyla tek bir cümleyle anlatılabilmektedir. Atasözlerinde, gündelik hayatın bir parçası olan, sosyal hayatta sürekli karşımıza çıkan kavramlar görülür. Bunlardan biri de insanoğlu için oksijen ve geçim kaynağı olmasının yanı sıra bazen bir barınak, bazen de meyvesi ile önemli bir besin maddesi olan ağaçtır. Yüzyllar boyunca Türklerin hayatında geniş bir yer tutan bu kavramın önemi dile de yansımış, kelimenin anlam alanında genişlemeler olmuş ve "sopa"dan "uzunluk ölçüsü”ne kadar pek çok anlam kazanmıştır (Arslan Erol, 2014: 729). Ağaç, Türkçe Sözlük'te "1. Meyve verebilen, gövdesi odun veya kereste olmaya elverişli bulunan ve uzun yıllar yaşayabilen bitki, 2. Bu gibi bitkilerin gövdesinden ve dallarından yapılan, 3 . Tahta, kereste" anlamlarında verilmektedir (TDK, 2019: 37). Orhun yazıtlarında ıgaç şeklinde gördüğümüz kelime, Karahanlı Türkçesinden itibaren y protezi ile yıgaç olarak karşımıza çıkar. Eski Türkçede $\imath$ "ağaç, orman" kökünden küçültme görevinde sözcükler türeten $+g A c ̧$ isimden isim yapım eki ile türetildiği düşünülmektedir (Erdal, 1991: 84). Çağdaş lehçelerde kelimeyi Azr. ă̆ac, Bşk. ağas, Kzk. ağaş, Krg. clğaç, Özb. däräht, Tat., Tkm. ă̆aç şeklinde görürüz (Ercilasun vd., 1991: 8, 9).

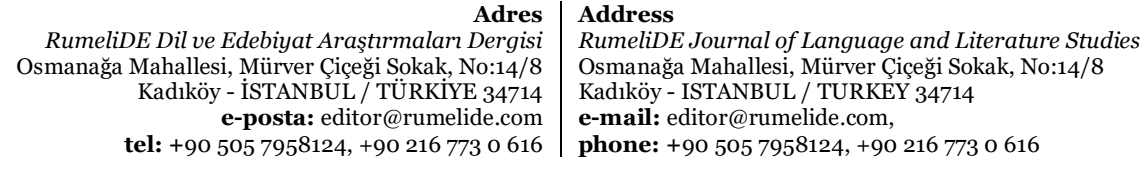


Ağacın ya da belli ağaç türlerinin kutsal kabul edilmesi, Türk toplulukları arasında yaygın olan inanışlardan biridir. Ağaç kültü, dinler tarihçilerinin tespitine göre insanlık tarihinin en eski zamanlarından beri yeryüzünde kendini göstermektedir. Yerin dibine kadar uzanan kökleri, göğe doğru dik bir şekilde yükselen gövdesi, gökyüzüne dağılan dalı, budağı, yaprakları, mevsimden mevsime kendini yenilemesi gibi pek çok özelliği ile iptidai insanın dinî telakkilere sahip olmasında önemli rol oynamıştır. Ağaç, çoğu defa hayatın ve ebedîliğin timsali olarak da kabul edilmiştir (Ocak, 2002: 129). Türklerin kutsal kabul ettikleri ağaçlar, meyvesiz, ulu, açık renkli, gölgeli ve kaba olup bunların başında kayın, çam, dağ servisi-sedir, ardıç ve çınar gelmektedir (Ergun, 2004: 195, 196). Türk düşüncesindeki ağaç kültünün özünü "Hayat Ağacı" oluşturur. Hayat ağacı neredeyse bütün kültürlerde yaratılışın kaynă̆ı ve yer altından gökyüzüne, Tanrı’nın olduğu mekâna ulaşabilen dünyanın direği olarak algilanmıştır (Ergun, 2004: 392).

İnsanlığın yaratılışı hakkındaki Türk düşüncesine göre Tanrı önce yerden dokuz dallı ağacı yükseltmiş, sonra bu ağacın her bir dalı altında bugünkü insanlığın atalarından birini yaratarak bu dokuz insanı ağaç gölgesinde barındırmıştır (Banarlı, 1983: 31). Ağaç, Türk boylarının menşei hakkında söylenen efsanelerde önemli bir yer tutar. Uygurların türeyiş efsanesinde Uygur hakanlarının ağaçtan türedikleri söylenir. Oğuz destanlarında Kıpçak boyunun menşei hakkındaki rivayette de ağaçtan türeme efsanesinin izleri vardır. Bu rivayete göre Oğuz Han'ın sefer dönüşünde, savaşta ölen bir askerin eşi ağaç kovuğunun içinde bir oğlan doğurur. Oğuz Han bu çocuğu evlat edinir ve Kıpçak (ağaç kavuğu) adını verir (İnan, 1986: 65). Dede Korkut Kitabı'nda Basat, "atam adın șorar olsañ ḳaba ağaç, anam adın diriseñ kağan aṣlan” şeklinde kendinden söz eder (Ergin, 2016: 214).

Ağaç, tasavvuf edebiyatında da karşımıza önemli bir sembol olarak çıkmaktadır. Bir çekirdek bütün bir ağacın bilgisini taşır ve uygun ortamı bulduğunda bu bilgi açığa çıkar, büyür, dallanır, yapraklar çıkar ve meyve verir. Fiziksel olarak bir olan çokluğa dönüşür. Ağaçtan beklenen meyve elde etmek olup meyvesi olmayan ağaç makbul değildir. Kâinat da bir ağaç gibidir. Ağacın tohumu hakîkat-i Muhammediyye, ağacın meyvesi ise insan-ı kâmildir ve önemli olan da insan-ı kâmil olmaktır (Yücer, Küçük, 2019: 13). Yunus Emre, kişinin tasavvufî manada olgunlaşmasını şiirinde ağaç sembolüyle anlatır:

\section{"Âşık olmayan âdemî}

Benzer yemişsiz ağaca

Ağaç yemiş vermeyince

Budağı eğilmez imiş” ～(Tatçı, 2009: 61)

Anonim halk edebiyatının kısa türlerinden olan atasözlerinde de ağaç kavramının önemli bir yer tuttuğu görülür. Türkiye Türkçesi atasözleri içerisinde ağaçla ilgili olanlar sayıca fazladır. Meyvesi, çiçeği, yaprağı gibi estetik özellikleriyle dikkat çeken ağaç, doğumdan ölüme kadar hayatın her safhasında kullanılması dolayısıyla da toplumların ilgisini çekmiştir. Bu ilgi atasözlerine de yansımış ve ağaca zarar verilmemesi gerektiği "baş kes, yaş kesme", "yaş kesen baş keser" atasözleriyle ifade edilmiştir. Ağaç için bazı yörelerde "ağacı çok olan yerde kıtlık olmaz", "ağaç sevgisi, evlat sevgisidir”, "ağaç yurdun gelinidir", "ağaçlı köyü sel basmaz", "ağaçsız memleket duvaksız geline benzer", "baltanı taşa çal, ağaca değme”, "yaş kesen el kurur" denilmiştir. Atasözlerinde ağaç çoğunlukla insanı işaret etmiş, bazen de kökü, dalı ve yaprağı ile aile, akraba, eş dost, toplum gibi kavramları çağrıştırmıştır. "Ağaç yaprağıyla gürler (güzeldir)”, "ağaç dalıyla gürler”, "ağaç ağaç içinde büyür (yetişir)”, "ağaç düşse (düşer) de yakınına rastlanır”, "ağaç kökünün üstünde biter”, "her ağaç kökünden kurur (çürür)” gibi örnekler verilebilir. Alçak gönüllü olma, azimli olma, sabırlı olma, öngörülü olma gibi pek çok değeri anlatmak için ağaç

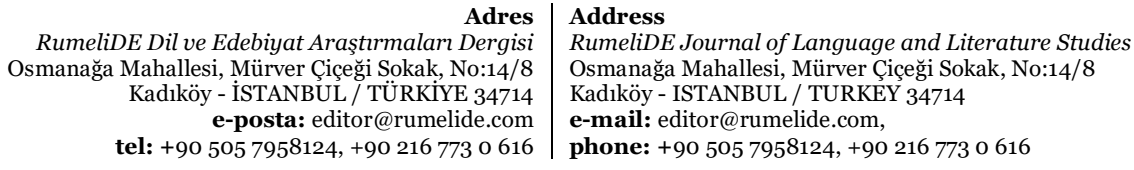


kavramından yararlanılmıştır. "Ağacın meyvesi olunca başını aşağı salar”, "bir vuruşla ağaç devrilmez", "acele bir ağaçtır, meyvesi pişmanlıktı»", "aklına gelene işleme, her ağacı taşlama” şeklinde örnekler çoğaltılabilir. Atasözlerinde genel olarak ağaç kavramına yer verilmesinin yanı sıra pek çok ağaç türünden de bahsedilmiştir. Çalışmamızda ağaç türleri incelenmiş olup ayrı kavramlar olması nedeniyle ağacın meyvesi ve çiçeği ile ilgili olan atasözleri çalışmaya dâhil edilmemiştir. Taradığımız kaynaklarda tespit ettiğimiz ağaç türleri şunlardır: ${ }^{2}$

\section{Ardiç}

Türkçe Sözlük’te ardıç, "servigillerden, güzel kokulu yapraklarını kışın da dökmeyen, yuvarlak kara yemişleri ilaç olarak kullanılan bir ağaççık (Juniperus)" olarak geçer (TDK, 2019: 147). Ardıç kelimesinin değişkeleri çağdaş lehçelerde şu şekillerde karşımıza çıkmaktadır: Azr. ardıç, Tkm., Krg., Özb. arça, Kzk., KKlp. arşa, Alt. arçın, Tuv., Bşk., Tel. artış, YUyg. ardaç (Eren, 1999: 15). Kelime, ilk olarak Eski Uygur Türkçesi metinlerinde artuç olarak görülür. Uygurlarda artuç urugì yani "ardıç tohumu" ilaç olarak kullanılmıştır (Ögel, 1995: 472). Bir Uygur şiirinde "artuç sögüt butıkı yüz türlügin ırgalur" diye bir ifade yer alır (TT I 164, 165; Bang, Gabain, 1929: 252). Artuç, Kaşgar'da iki köyün adı olarak geçer (Ercilasun, Akkoyunlu, 2015: 46). Dîvânu Lugâti’t-Türk’te verilen şiir örneklerinde de ardıç ağacına rastlarız.

ardı sini kìz bodı anì tāl

yaylir anı̇ artuçı burnı takı kıwal

"Bir kızı tasvir ederek diyor ki: Bedeni körpe, vücudu nazlı nazlı salınan, ardıç dalı gibi titreyen, burnu biçimli kız seni aldattı” (Ercilasun, Akkoyunlu, 2015: 178).

kim ayıp iştür kulak

ay ewi artuç butak

"Hangi kulak duydu ve kim dedi ki ayın evi ardıç dalıdır." Kaşgarlı Mahmut, burada cariyenin nitelenerek yüzünün aya, boyunun da ardıç dalına benzetildiği söyler (Ercilasun, Akkoyunlu, 2015: 162).

Uzun ömürlü, düz ve uzun boylu bir ağaç olan ardıç, dîvan şiirinde de karşımıza çıkmaktadır. Dîvan şairleri ardıç yerine Arapça 'ar'ar kelimesini kullanmış ve sevgilinin boyu 'ar'ara benzetilmiştir (Bayram, 2001: 935).

\section{Yüzüñ enver sözüñ şekker gözüñ 'abher özüñ server}

Boyuñ 'ar'ar būyuñ 'anber dişüñ gevher șaçuñ Hindū (Şeyhî, G. CL-4)

Ardıç, Türk dünyasında önemli ağaçlardan biridir. Temizlik ve kutsallığın sembolü sayılan bu ağacı Altaylılar kötü ruhlardan korunmak için kullanır. Ardıç dallarını yakıp her yeri tütsüleyerek kötülüklerin ve hastalıkların uzaklaştııılacağına inanılır. Ancak tütsü ya da ilaç için ardıç dalı alınacağı zaman dikkat edilmesi gereken hususlar vardır. Dalı alacak kişi öncelikle temiz olmalıdır. Dal alınmadan önce çaput bağlanmalı, Tanrı'ya dua edilmeli ve dalı almak için izin istenmelidir. Dal mutlaka kuzeye doğru eğilerek kırılmalı ve bunu yaparken diğer dalların yaralanmamasına dikkat edilmelidir. Ardıç ağaçlarının

Çalışmamızda taranan kaynaklar: Ali Püsküllüoğlu (2012). Türk Atasözleri Sözlüğü. Ankara: Arkadaş Yayınevi; Kerim Yund (1944). Ağaç, Orman Üzerine Atasözleri ve Açıklamaları. Ankara: Recep Ulusoğlu Basımevi; Metin Yurtbaşı (2012). Sinıflandırılmış Türk Atasözleri. İstanbul: Excellence Dictionaries; Ömer Asım Aksoy (2020). Atasözleri ve Deyimler Sözlüğü 1, Atasözleri Sözlüğü. İstanbul: İnkllâp Kitabevi; TDK Atasözleri ve Deyimler Sözlüğü https://sozluk.gov.tr/; TDK (2019). Bölge Ağızlarında Atasözleri ve Deyimler. Ankara: Türk Dil Kurumu.

Adres $\mid$ Address

RumeliDE Dil ve Edebiyat Araşturmalar Dergisi $\quad$ RumeliDE Journal of Language and Literature Studies Osmanağa Mahallesi, Mürver Çiçeği Sokak, No:14/8 $\quad$ Osmanağa Mahallesi, Mürver Çiçeği Sokak, No:14/8 Kadıköy - ÍSTANBUL / TÜRKIYE 34714 Kadıköy - ISTANBUL / TURKEY 34714 e-posta: editor@rumelide.com e-mail: editor@rumelide.com, tel: +90 505 7958124, +90 2167730616 phone: +90 505 7958124, +90 2167730616 
bulunduğu yerde gürültü yapılmamalı, kötü söz söylenmemelidir. Olumsuz tavırlar sergileyenlerin hastalık ya da ölümle cezalandırılacağına inanılmaktadır. Dal, kesinlikle kesilerek alınmamalıdır. Ardıç dalının kesilmesi ya da koparılmaması gerektiği, bunu yapanların başlarına bela geleceği inancı Anadolu'da devam etmekte olup çeşitli hastalıkların tedavisi için de ardıç ağacından yararlanıldığı bilinmektedir (Ergun, 2004: 226-228).

Ardıç, atasözleri içerisinde yaygın bir kullanıma sahip değildir. Ardıç ağacının ateşi çabuk geçer, kül olur. Yalancının sözü de böyledir, ona güvenilmez manasında atalarımız "ardıcın közü olmaz, yalancının sözü olmaz” demiştir. Ağızlarda “ardıcın közü, çingenenin sözü” şekli de görülmektedir. Ardıç, çok uzun zamanda yetişmesi, dayanıklı kerestesi, hoş kokusu ve şifa kaynağı meyveleriyle insan hayatında önemli bir yer tutar. Kış aylarında bile yapraklarını dökmeyip doğal yapısını koruyan bu ağacın gölgesi için de "ardıç gölgesi kardeş gölgesi, söğüt gölgesi yiğit gölgesi” denilmiştir.

\section{Asma}

Asma, "belli bir cins üzüm veren, dalları çardak üstüne yayılan tırmanıcı küçük ağaççı, üzüm ağacı" şeklinde tanımlanır (Ayverdi, 2011: 190). Yabani asma olarak bilinen ilk asma bitkisinin anavatanı konusunda kesin olmamakla birlikte Kafkaslar, Afganistan'dan başlayarak Türkiye ve aşağı Mezopotamya'yı içine alan, hatta İspanya'ya kadar uzanan geniş bir coğrafya işaret edilmektedir. Vitaceae familyasından olan asmanın pek çok türü olmakla birlikte bağcılıkta en sık kullanılanı ve en değerlisi Vitis vinifera Linne'dir (Anlı, 2006: 19, 20). Uygun iklim koşulları dolayısıyla ülkemiz bağcılık için dünyanın en önemli bölgelerinden biridir.

Yeryüzünde önemli bir kültür bitkisi olan asma, milyonlarca yl önceye dayanan köklü bir geçmişe sahiptir. Anadolu'da milattan önce büyük bir uygarlık kuran Hititlerden kalma tarihî bulgularda asmaya rastlanmakta, bağcılığın ekonomide önemli bir rolü olduğu görülmektedir. Hitit kanunlarında bağların çitlerle korunduğundan, bağda bulunan asmanın yakılması, çalınması, zarara uğratılması hâlinde ağır para cezalarının verildiğinden bahsedilir (Deliorman Orhan vd., 2011: 71).

Bağcllı ve üzüm kültürü Türkler tarafindan eski dönemlerden beri bilinmektedir. Asmanın meyvesi üzüm, tarihî dönemlere baktığımızda ilk olarak Uygur metinlerinde karşımıza çıkar. Türkçe olan kelimenin üz- "kopar-, kes-“ kökünden türediği bilinmektedir (Clauson, 1972: 288). Dîvânu Lugâti”tTürk’te üzüm ağacı anlamında üzüm yıgaçı denildiğini görmekteyiz (Ercilasun, Akkoyunlu, 2015: 352). Asmanın as- kökünden -ma fiilden isim yapım ekinin kalıplaşmasıyla türediği kabul edilmektedir (Ayverdi, 2011: 190).

Asma, geçmişten günümüze meyvesi ve yaprağı ile besin maddesi olarak kullanılmasının yanı sıra tedavi amaçlı da kullanılmıştır. İnsanlar üzümü hem taze hem de kurutarak tüketmiş, onu şarap yapımında kullanmıştır. Sözlü kültür geleneğinde de önemli bir yere sahip olan üzüm, bolluk bereket, güzellik, aşk, sağlık sembolü olarak görülmüştür (Şenocak, 2007: 172). Hammaddesi üzüm olan ve mitolojide Tanrıların içkisi olarak kabul edilen şarap, Tevrat, İncil ve Zebur'da kutsal içki olarak anılmıştır (Şenocak, 2007: 167). Şarabın ortaya çıkışı ile ilgili yaygın olarak anlatılan efsanelerden biri şöyledir: "Nuh peygamber üzüm veren asma yetiştirmek istedi. Fakat şeytan diktiği asmaları bağa gelerek kurutuyordu. Bir gün Nuh onu suçüstünde yakaladı. Şeytan Nuh’a: Bu bağlardan edeceğin kâra beni de ortak yaparsan asmalarına karışmam, dedi. Nuh razı oldu. Şeytan; arslan, keçi, maymun ve domuz kanlarını karıştırarak asmaları suladı. Üzümler yetişti. Nuh, kendi payına düşen üzümle pekmez, şıra, pestil yaptı. Şeytan da kendi payıla sirke ve şarap yaptı ve dedi ki: Yaptığım şaraptan her kim bir miktar

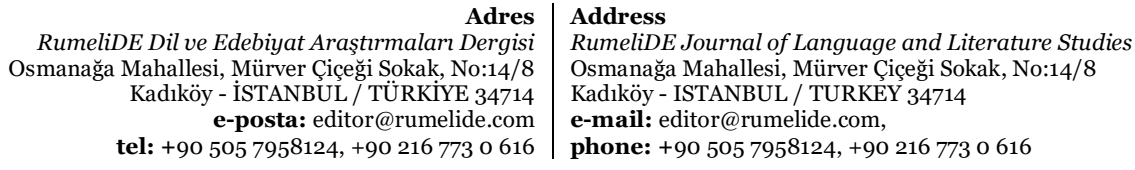


içerse arslan gibi kuvvetli olsun. İki miktar içen keçi inatlı, fazla içen maymun iştahlı, pek fazla içen domuz kinli ola. İşte o günden beri şaraba bu beddua sindi” (Ünver, 1949: 17, 18).

Asma, atasözlerinde de karşımıza çıkmaktadır. "Soy asma, soyuna çeker” örneğinde temiz soydan gelen kişinin, ailesindeki olumlu özellikleri taşıyacağı, soylu aileden geldiğini hâl ve hareketleriyle belli edeceği vurgulanır. Kişinin iyi yerlere geleceği, yaptığı işlerde başarılı olacağ başlamasından bellidir manasında "üzüm olacak asma kökünden belli olur" denir. "Miskin asmanın kel koruğu, bir gün gelir tepene çıkar” atasözü ise değersiz, işe yaramaz birine yüz verirsen gün gelir sana hükmetmeye kalkar anlamında kullanılır.

\section{Ceviz/Koz}

Türkçe Sözlük’te ceviz, “cevizgillerin örnek bitkisi olan, uzun ömürlü, gövdesi kalın, kerestesi değerli, yurdumuzda çok yetişen ağaç (Juglans regia)” olarak geçer (TDK, 2019: 458). Ceviz, dilimize Arapça cevz'den geçmiş bir sözcük olup cevz de Farsça gavz'dan alıntıdır. Koz ise doğrudan Farsça gavz'dan Türkçeye girmiştir. Aynı kökene dayanan ve Türkçeye farklı dillerden farklı dönemlerde geçen bu iki kelimeyi Eren, doublet örnekleri olarak verir (1995: 733). Eski Türkçede ceviz yerine yagak kelimesi karşımıza çıkar: Yagak ıgaç yaylagım, kuşlug ıgaç kışlagım "Ceviz ağacı yazlığım, kuşlu ağaç kışlığım” (IrkB. 56; Tekin, 2013: 25). Arapça ve Farsçadan alıntı ceviz ve koz kelimeleri Türkçe yagak'ın yerini almıştır. Türkiye Türkçesinde standart dilde yaygın olarak ceviz kullanılırken mecazi adlandırma daha çok koz kelimesi kullanılmaktadır (Erdağı Doğuer, 2018: 155).

Atasözlerine baktığımızda ceviz/koz ağacı çeşitli özellikleriyle karşımıza çıkar. "Ceviz gölgesi yavuz gölgesi, söğüt gölgesi yiğit gölgesi” ile "koz gölgesi kız gölgesi, söğüt gölgesi yiğit gölgesi, dut gölgesi it gölgesi” örneklerinde bu ağacın gölgesine olumsuz bir yaklaşım olduğunu görmekteyiz. Aksoy, bu atasözlerinin açıklamasını "ceviz ağacının gölgesi koyu, güzeldir. İnsana kızların yanında bulunma keyfi verir. Ancak orada karınca çok olur; gölgede oturan insanın keyfini kaçırır. Kızların yanında oturan kişi de hem mutluluk duyar, hem de çevredeki asalaklardan rahatsız olur" şeklinde yapar (2020: 368, 369). Bazı yörelerde ceviz ağacının tekin olmadığına, altında uyumanın uğursuzluk getirdiğine inanılır. Anadolu'da "ceviz ağacının dibinde ve gölgesinde oturulmaz, adamı erken öldürür" denilmektedir. Bu söz gerçekliği tartışllan bir iddiaya dayanır. İddiaya göre ceviz ağacı sülfür gazı salgılar. Bu gaz, havadaki diğer gazlardan daha ağır olduğu için dibe çöker ve insanı sersemletir. Bu nedenle de ceviz gölgesi pek makbul değildir (https://ww w.tarim.com.tr/Ceviz-Agacinin-Altinda-Oturmak-Neden-Tehlikeli,3 9549 h).

25-30 metreye kadar yükselebilen bu ağaçlara tırmanmanın zorluğundan dolayı cevizler silkme tekniğiyle toplanır. "Ay ışığında ceviz (kestane) silkilmez" atasözü yeterli olmayan koşullarda yapılan işlerden beklenilen verim alınamaz anlamında dilimizde kullanılır. Yurtbaşı bu atasözünü "gizli işler herkesin önünde yapılmaz” şeklinde açıllar (2012: 239). “Ceviz zamanında çırpılır” örneği ile de her işin vaktinde yapılması gerektiği öğütlenmektedir.

Ülkemizin tüm bölgelerinde yetişebilen ceviz ağacının meyvesi, hem insanlar hem de kargalar tarafından sevilmektedir. Kargalar topladıkları cevizleri uçuş mesafelerindeki değişik yerlere gömer, sonradan yemek istediklerinde çoğunlukla bulamaz ya da artık o cevize ihtiyaç duymaz. Böylece o cevizler zaman içinde filizlenir. Bir atasözünde cevizin yanında kızılcığın da anıldığını görmekteyiz. Kızılcık, genellikle doğada yabani olarak kendiliğinden yetişen bir ağaçtır. Ceviz ve kızılcığın bu durumu

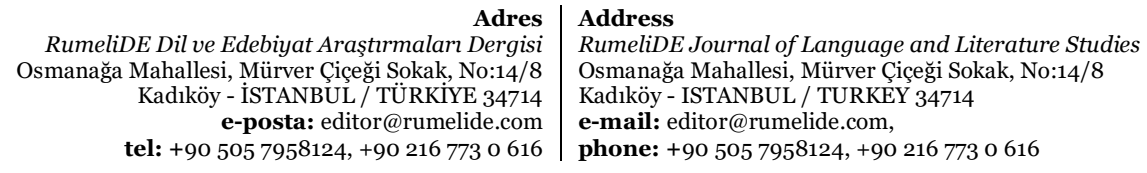


atasözlerine bazı işler emek verilerek yapıldığı hâlde bazıları kendiliğinden olur manasında "cevizi karga diker, kızılcık kendi biter" şeklinde yansımıştır.

\section{Çam}

Çam, "çamgillerin örnek bitkisi olan, dört mevsim yeşil kalabilen, iğne yaprakll, yurdumuzda birçok türü yetişen bir orman ağacı (Pinus)” şeklinde tanımlanır (TDK, 2019: 489, 490). Türkiye'de yetişen türlerine kızılçam, Halep çamı, karaçam, sahil çamı, fıstık çamı, sarıçam gibi adlar verilmektedir (Baytop, 2007: 65). Arapça şem" "mum"dan; şem > şam > şam ă̆acı "çıra ağacı" > çam ağacı, kısaltma yoluyla çam şeklini almıştır (Ayverdi, 2011: 531). Yerel ağızlarda şam olarak da geçer. Çağdaş lehçelerde Azr. şam, Bşk. karağay, şirşı, Kzk. karağay, şırşa, Krg. karağay, Tat. narat, Tkm. arça şeklinde görülür (Ercilasun vd., 1991: 114, 115). Tarihî dönemlere baktığımızda Eski Uygurcada çam ağacı anlamında tıt kelimesi karşımıza çıkmaktadır (Caferoğlu, 2011: 238). Kaşgarlı da tıt kelimesini "çam ağacı, dağlarda yetişir" açıklamasıyla verir (Ercilasun, Akkoyunlu, 2015: 396).

Türk kültüründe, özellikle de Kuzey Türklerinde çamla ilgili inanışlar oldukça yaygındır. Çam ağacının türleri farklı semboller taşır. Karaçam ve kızılçam erkeği temsil ederken fistık çamı kadını temsil etmektedir (Ergun, 2004: 208). Çam ağacının yaz kış yeşil kalması, uzun ömürlü olması, dağların tepesinde tek başına olması, meyvesiz oluşu, büyüklüğü Tanrı'nın sıfatlarını sembolize eder (Ergun, 2004: 211).

Klasik Türk edebiyatında çam ağacının karşllı̆̆ı olarak Arapça sanevber kelimesini görürüz. Sevgilinin boyu ile sanevber arasında bağlantı kurulmaktadır (Bayram, 2001: 928).

\section{Çü ḳaddüñ ḳāmetin gördi șanevber secdeler kıldı}

Şu ḳadd ü ḳāmete ḳarşu mü'ezżin bu ne ḳāmetdür (Şeyhî, G. LXXIII-2)

Atasözlerine baktığımızda, çam ağacıyla ilgili örneklerin özellikle ağıllarda fazla olduğunu görürüz. Çam, atasözlerinde daha çok fiziksel ve kimyasal özellikleriyle ön plana çımıştır. Çam ağaçlarının 50 metreye kadar uzayabilen türleri vardır. "Uzunda hüner olsa, çamda hıyar biter", "büyüklükte hüner olsa, çamda hıyar olurdu" atasözleriyle uzun ya da büyük olmanın tek başına bir değer ölçütü olmadığ 1 anlatılmak istenmektedir.

Çabuk yanan bir ağaç olan çam, uzun süreli kullanımlara pek uygun değildir. Dolayısıyla ondan ağıl yapmak doğru olmaz. Her şeyin bir değeri vardır, kullanılacağı yer ayrıdır anlamında "çam ağacından ağıl olmaz, el çocuğundan oğul olmaz" denilmektedir. "Eloğlu oğul olmaz, çam ağacı ağıl olmaz", "çam dalı ağıl olmaz, eloğlu oğul olmaz", "eloğlundan oğul, çam dalından ağıl olmaz” gibi şekilleri de mevcuttur. Kozalaklı bir ağaç olması "anadan olur buză̆ı, çamdan olur kozak", yandıktan sonra arkasında köz bırakmaması "çamın közü, yalancının sözü olmaz" şeklinde atasözlerine yansımıştır. Ağızlarda “çam odununun özü mü olur, çingenenin sözü mü olur?” da denilmektedir.

Çam ağacının bazı türlerinin gövdelerinde halk arasında basra böceği diye adlandırılan bir böcek yaşar. Bu böcek çam ağacının öz suyunu emerek bir salgı bırakır. Bu salgı bal arıları tarafından alınıp kovana taşınır ve bala dönüşür. Bal da ayıların sevdiği besinlerdendir. Bir şeyin değerini en iyi onu yakından tanıyan bilir manasında "çamın haysiyetini ayıdan sor" denilmiştir. "Yağlı domuz, yağlı çama sürünür" atasözüyle herkesin içinde bulunduğu duruma, karakterine uygun hareketler sergileyeceği anlatılır.

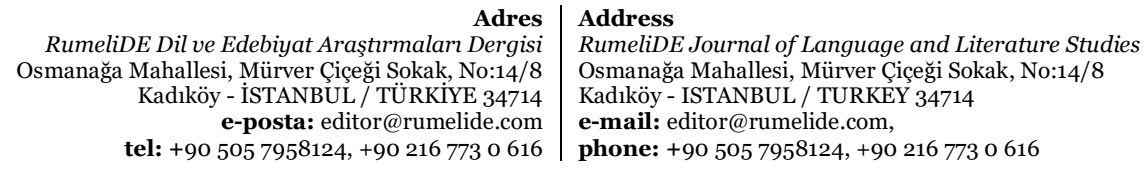


Çam gibi reçineli ağaçların yağlı ve çabuk yanmaya elverişli kısımları olan çıra, geçmişten günümüze genellikle ateş yakma amacıyla kullanılmıştır. Çıra, eski dönemlerde aynı zamanda aydınlatma aracı vazifesi de görmüştür. Mumdan daha fazla alevlenmesinden dolayı daha geniş çaplı bir aydınlatma sağlamaktadır. Tanrı çok isteyip çok çalışana çok, aza kanaat edip az çalışana da az verir manasında "Allah çam isteyene çam, mum isteyene mum verir" denilmiştir. Güçlü, varlıklı bir kimse güçten düştüğünde dostunun kalmayacağına, etrafının çıkarcı insanlarla dolacağına işaret eden "bir çam düşse baltalı da seyirtir, baltasız da", "yaralı çama balta vuran çoktur” örnekleri mevcuttur. "Balta değmedik çam, yıkılmadık dam olmaz” atasözü zarar görmeyen, yıkıma uğramayan kimse yoktur mesajı verir. Ağızlarda kullanılan "dağ başında çam kadı, pelit müftü” atasözünde şehirden uzakta, kanun ve nizamın yeterli olmadığı yerlerde yaşayanların çaresizlikleri anlatılmakta olup orman ağacı olan çam ile kadı arasında ilişki kurulmuştur.

Evliya Çelebi, Seyahatname'de Bolu'yu anlatırken “(...) ab-ı hayat suları ve kutu bozası ve çam ve ardıç bardakları olur kim andan su içen ab-ı hayat-ı cavidan bulur. Ol diyarda ona senek ve boduç derler" notunu düşer. Çam ağacının suyu soğuk tutma ve ona hoş bir koku verme özelliği vardır. Çam ormanlarından çıkan kaynak suları da meşhurdur. Çam ormanlarının bulunduğu bölgelerde ağaçtan yekpare bardaklar yapılmıştır. Pala, konuyla ilgili olarak şu hikâyeyi aktarır: "Vaktiyle orman köylerinden bir delikanlı, askere gitmiş. O ylllarda askerlik de uzun sürüyor hani. Geri döndüğünde köyün yakınındaki büyük çam ağaçlarının kesildiklerini görüp babasına sebebini sormuş. İşte cevap: - Oğlum, sorduğun o eski çamlar bardak oldu. Askerde iken sana gönderdiğimiz harçlıklar nereden geldi sanıyorsun?" (2020: 80, 81). Eski durumların tamamıyla değiştiğini anlatmak için günümüzde de "eski çamlar bardak oldu"3 denilmektedir.

\section{Çinar}

Kubbealtı Lugatı'nda çınar için “iki çeneklilerden, boyu 30 metreyi bulabilen, gövdesi kalın, yaprakları parçalı, uzun ömürlü, gölgesi koyu olduğu için park ve bahçelere süs ağacı olarak dikilen büyük ağaç (Platanus)" denilmektedir (Ayverdi, 2011: 584). Azr., YUyg. çinar, Bşk., Tat. çinar(a), Kzk. şınar, Krg. çınar, Özb. çinàr, Tkm. çmār şeklinde görülür (Ercilasun vd., 1991: 128, 129). Kelime, Farsçada aynı anlama gelen çenār sözcüğünden alıntıdır. Kaşgarlı'ya göre Yağma lehçesinde çınar ağacına çarun denilmektedir (Ercilasun, Akkoyunlu, 2015: 179). Kaşgarlı'nın çınar ağacı anlamında verdiği diğer kelime ise çünük/şünük olup ç'nin ş’ye dönüşmesinden şünük şeklini almıştır (Ercilasun, Akkoyunlu, 2015: 167, 168). Çınar, kabukları soyulup döküldüğü için ağızlarda kavlağan olarak da adlandırılır (DS VIII, 1993: 2689 ).

Çınar, görkemli ve uzun ömürlü bir ağaçtır. Bu hâliyle geçmiş ile gelecek arasında bir köprü vazifesi görür. Toplumun hafızasında iz bırakan olayların anısını bugüne taşıdıkları için de toplum tarafından korunur ve saygı gösterilir. Türkler çınarı "ulu ağaç" olarak kabul etmiştir. (Ögel, 1995: 477). Türk toplumu, özellikle de Osmanlı Devleti için çınarın ayrı bir değeri vardır. Osmanlılar zamanında saray, medrese, cami gibi pek çok yerin çevresine çınar ağacı dikilmesi dikkat çekicidir. Çınarın ihtişamlı görünüşü ve yüzyıllar boyu yaşayabilen bir ağaç olması dolayısıyla devletin gücünü ve ebedîliğini sembolize ettiği görülmektedir. Bazı araştırmacılar, Osmanlı ile çınar ağacı arasındaki ilişkiyi devletin kurucusu Osman Bey’in rüyasında gördüğü iddia edilen dünyayı saran çınar ağacına dayandırır. Osmanlı Devletinin kuruluşuyla ilgili rüya şu şekildedir: "Osman Gazi niyâz etdi ve bir lahza ağladı. Uyku galib oldı. Yatdı, uyudı. Gördi kim kendülerün aralarında bir aziz şeyh var idi. Haylı kerâmeti zâhir olmış idi. Ve cemi` halkun mutekadıyidi. Adı derviş idi. Ve illâ dervişlük bâtınındayidi. Dünyesi ve ni'meti, davarı çoğ idi. Ve

3 TDK Atasözleri ve Deyimler Sözlüğ̈̈ https://sozluk.gov.tr, Kerim Yund (1944: 44) ve Metin Yurtbaşı (2012: 150) atasözü olarak kabul ederken, Ömer Asım Aksoy (2019: 769) ve Ali Püsküllüoğlu (2017: 336) deyim olarak vermektedir.

Adres Address

RumeliDE Dil ve Edebiyat Araştrmaları Dergisi $\quad$ RumeliDE Journal of Language and Literature Studies

Osmanağa Mahallesi, Mürver Ciiçeği Sokak, No:14/8 Osmanağa Mahallesi, Mürver Çiçeği Sokak, No:14/8

Kadıköy - İSTANBUL / TÜRKIYE 34714 Kadıköy - ISTANBUL / TURKEY 34714

e-posta: editor@rumelide.com $\quad$ e-mail: editor@rumelide.com,

tel: +90 $5057958124,+90216773$ o 616 phone: +90 505 7958124, +90 2167730616 
sâhib-i çeră̆ ve ‘alem idi. Dâyım misâfirhânesi hâlî olmaz idi. Ve Osman Gazi dahı gâh gâh gelür idi. Bu azize konuk olur idi. Osman Gazi kim uyudı, düşinde gördi kim bu azizün koynından bir ay doğar, gelür Osman Gazinün koynına girer. Bu ay kim Osman Gazinün koynına girdügi demde göbeginden bir ağac biter. Dahı gölgesi âlemi dutar. Gölgesinün altında dağlar var. Ve her dağun dibinden sular çıkar. Ve bu çıkan sulardan kimi içer ve kimi bağçalar suvarur ve kimi çeşmeler akıdur. Andan uyhudan uyandı. Sürdi, geldi. Şeyhe habar verdi. Şeyh eyidür: "Oğul, Osman! Sana muştuluk olsun kim Hak Ta‘âlâ sana ve neslüne padişahlık verdi. Mubârek olsun.” der. Ve "Benüm kızum Malhun senün helâlün oldı” der. Ve hemandem nikâh edüb kızını Osman Gaziye verdi” (Âşıkpaşaoğlu Âşıkî, 1949: 95).

Çınar, dîvan şiirinde de her dönem şairlerin ilgisini çekmiştir. Kumruların dallarına yuva yapması, geniş gölgesinin oluşu, yıldırımı çekip yanması, uzun olması nedeniyle sevgilinin boyu ile ilişkilendirilmesi, yapraklarının insan eline benzemesi gibi hususlarda ele alınmıştır (Bayram, 2001: 910-918).

Atasözlerinde çınar ağacına "çocuklu kadın, kargalı çınar, civcivli tavuk" örneğinde rastlamaktayız. Geleneksel toplumlarda kadının “doğurgan” olması önemli bir husustur. Anne kimliği kadına ayrı bir statü kazandırır. Çocuğun yetiştirilmesinde sorumluluğun çoğu da annenin üstündedir. Çocuğu olan bir kadın evladını etraftan gelebilecek tehlikelere karşı nasıl koruyor, kol kanat geriyorsa çınar ağacı da ihtişamlı gövdesi, geniş yapraklarıyla üstüne konan kuşları, dallarını mesken tutan kargaları koruyup saklamaktadır.

\section{Dut}

Dut, “dutgillerden, kuzey yarım kürenin genellikle ılıman bölgelerinde yetişen, yapraklarıyla ipek böceği beslenen ağaç (Morus)" şeklinde tanımlanır (TDK, 2019: 727). Kışın yapraklarını döken bu ağacın ak dut, kara dut, mor dut gibi türleri bulunmaktadır (Baytop, 2007: 95). Dut, Azr., Bşk., Kzk., Özb., Tat., YUyg. tut, Krg. tıt, Tkm. tūt şeklinde karşımıza çlkar (Ercilasun vd. 1991: 192, 193). Çağdaş Türk yurtlarında dar bir alanda geçen dut, Yakutlar ve Çuvaşlarda yetiştirilmemektedir (Eren, 2001: 683). Farsça tūt/tūd'dan alıntı olan kelime, Türkçeden Balkan dillerine geçmiştir (Eren, 1999: 124). Tarihî dönemlere baktığımızda dut anlamında Uygurcada çüsüm (Caferoğlu, 2011: 66), Dîvânu Lugâti’tTürk’te üjme (Ercilasun, Akkoyunlu, 2015: 65), Harezm Türkçesi eserlerinden Kısasü'l-Enbiyâ'da tut (Ata, 1997: 168) kelimelerini görürüz.

Geleneksel Türk düşüncesine göre evin temeli atılmadan önce etrafına ağaç dikilmesine özen gösterilir. Dut da o ağaçlardan biridir. Evin ruhu olarak kabul edilen dut ağacı, evin saadeti, istikbali ve bereketinin sembolüdür (Ergun, 2004: 238).

1970’lerde Özbekistan’ın güneyinde yapılan kazılarda M.Ö. 2. yüzyıla ait olduğu düşünülen bir mezarda göğsünde dut ağacı dalı bulunan kadın cesedi bulunmuştur. Kazıyı yapan Askarov, bunu eski Orta Asya topluluklarında ipek böceği yetiştiriciliği yapıldı̆̆ı şeklinde yorumlamıştır (İmer, 2005: 23).

Türkler pek çok alanda dut ağacının gövdesinden, şifalı meyvelerinden ve yapraklarından faydalanmıştır. Ağızlarda dut için "bir dutun verdiğini bir şey vermez” denilmektedir. İpek ve ipek böceği denildiğinde aklımıza ilk gelen ağaç duttur. Dut yaprağıyla beslenen ipek böcekleri kendine koza örmek için lif salgılar. Yumuşaklığı ve parlaklığıyla yüzyıllardır tercih edilen bu liften iplik yapılır, kumaş dokunur. Dut yaprağının atlasa dönüşme süreci, sabretmesini bilen kişi olmayacak gibi görünen işlerde bile başarı kazanır anlamında “sabırla koruk helva olur, dut yaprağı atlas” atasözünde karşımıza çıkar.

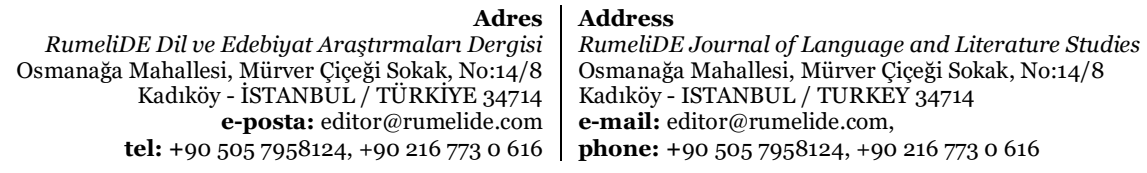


Ağaçların gölgeleri, onların doğal özelliklerini yansıtmaktadır. Dut ağacının gölgesi, altına meyveleri döküldüğü için dut yemek isteyenlerin doluştuğu bir yerdir. Ayrıca yere düşen dutlar etrafı kirletir ve oraya sinekler üşüşür. Bu nedenle de dut gölgesi rahatsız edicidir. "Koz gölgesi kız gölgesi, söğüt gölgesi yiğit gölgesi, dut gölgesi it gölgesi” atasözünde de dutun bu durumuna değinilmiştir. Atasözlerinde halk takviminin yansımalarını da görürüz. Düzenli olarak tekrarlanan doğa olaylarına ve canlıların hareketlerine dayalı yöresel takvimlere halk takvimi denilmektedir (Veren, 2019: 165). Halkın, dut ağacı yaprağını döktüğü zaman soğukların geldiği, yapraklanınca havaların ısınmaya başladığı gözlemi "dut yaprağı (ağacı) açtı, soyun; döktü giyin”, "kara dut yaprak döktü kış, kara dut yaprak açtı yaz", "dut yaprak açtı soyun, (dut) yaprak döktü giyin” şeklinde atasözlerine yansımıştır. Ağızlarda "dut (söğüt) suda dura dura olur abanız4, çoban kapıda kala kala olur babamız" diye bir atasözü karşımıza çıkar. Albayrak, bunu "sıradan bir şey zaman içinde tahmin edilemeyecek şekilde değer kazanabilir" şeklinde açıllamaktadır (2009: 372).

\section{Elma}

Elma, Kubbealtı'nda "gülgillerden, yurdumuzun her yerinde yetişen, dişli yapraklı, açık pembe çiçekler açan, verimli, dayanıklı ağaç (Pirus malus)” olarak geçer (Ayverdi, 2011: 855). Azr., Bşk., Kzk., Krg., Tat., Tkm., Y.Uyg. alma, Özb. àlmä şeklinde çağdaş lehçelerde görülmektedir (Ercilasun vd., 1991: 210, 211). Elma, kökeni tartışmalı kelimelerden biridir. Bazı araştırmacılar kelimeyi Hint-Avrupa dillerine dayandırır (Clauson, 1972: 146; Erdal, 1993: 27-36). Eski Uygur Türkçesinden beri dilimizde olan kelime alımla sögüt "elma ağacı" şekliyle karşımıza çıkar (Röhrborn, 1979: 93). Kaşgarlı Mahmut, kelimenin alma ve almıla olmak üzere iki söyleyişini tespit eder ve alma söyleyişinin Oğuzca olduğunu, Türklerin ise almıla ${ }^{5}$ dediğini belirtir (DLT, 1941: 77). Eserde almıla'nın alımla yazılışı da bulunmaktadır (DLT, 1941: 184). Şen, 11. yüzyılda farklı yazılışlar nedeniyle alma, almıla ve alımla olmak üzere üç söyleyişi görülen elmanın en eski şeklinin almla olduğunu ve ses hadisesi bakımından almla $>$ almıla $>$ alma şeklinde bir tarihî süreç izlediğini belirtir (2006: 573). Şen’e göre kelime, Eski Türkçe “kırmızı, pembe, turuncu" anlamlarına gelen $a l$ kökünden $a l+l+m+l a$ şeklinde türetilmiştir (2006: 579). Dilimizden Macarcaya alma şeklinde geçen elma, uluslararası bir sözcüktür (Eren, 2001: 683).

Kültürümüzde önemli bir yeri olan elma ağacı ve elma, destanlarda, masallarda, halk hikâyelerinde ve inanışlarda sıklıkla karşımıza çıkmaktadır. Manas Destanı'ndan Kerem ile Aslı Hikâyesi'ne kadar pek çok türde elma ağacı, elma ağacının dibinde yuvarlanma, elma ağacının meyvesinin eşler tarafından yenilmesi motifi görülür (Alptekin, 2007: 34). Bu ağacın meyvesi elma, bereketin, zürriyetin, ölümsüzlüğün, gençliğin, güzelliğin, sağlı̆̆ın sembolüdür (Şimşek, 2008: 193-204).

Atasözlerinde elma ağacına yetişme koşulları dolayısıyla yer verildiğini görmekteyiz. Elma, saçak kök yapısına sahip bir ağaç olduğu için oldukça fazla su ve nem ister. Elma ile birlikte atasözlerinde anılan armut ise kuraklığa dayanıklıdır, fazla su istemez. Bu nedenle elma fidanı düz ve sulak yere, armut ise bayıra, su tutmayan yerlere ekilmelidir. "Elmayı çayıra, armudu bayıra (dikmeli)", "elmanın dibi göl, armudun dibi yol (olmalı)" atasözleri bu gerçekliği yansıtırken mecazi olarak da her şeyin özelliğine göre davranmak gerektiği anlamı taşımaktadır.

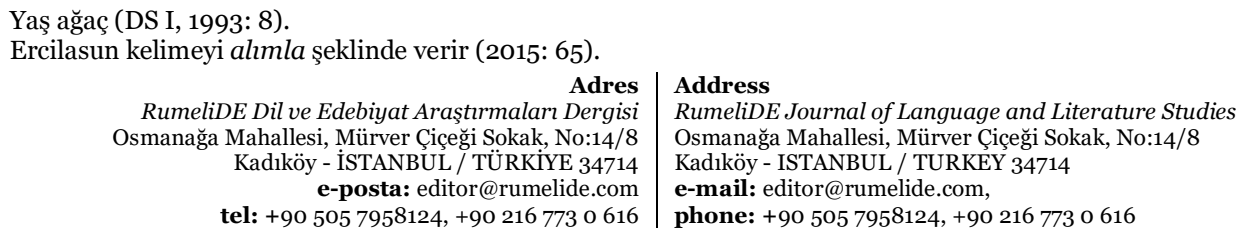




\section{Erik}

Erik, "beyaz çiçekler açan, her yerde yetişen ve pek çok türü bulunan meyve ağacı (Prunus domestica)"dır (Ayverdi, 2011: 880). Kelimenin olgunlaşmak manasındaki er- fiilinden türediği düşünülür (Gülensoy, 2007: 337). Eski Uygurca bir tıp metninde tülüg erüknüy kasıkın şeklinde bir ifadeye rastlarız (Clauson, 1972: 222). Bu metin, erük kelimesinin geçtiği en eski örneklerdendir. Kaşgarlı Mahmud erük için "şeftali, kayısı, siyah erik türünün genel adı. Birbirlerinden vasıflarıyla ayırt edilirler. Şeftaliye tülüg erük, kayısıya sarıg erük, siyah eriğe kara erük denir” açılaması yapar (Ercilasun, Akkoyunlu, 2015: 33). Bu durumda tülüg erüknüy kasıkın ifadesini "şeftalinin kabuğunu" şeklinde tercüme etmek uygundur. Günümüzde Azr. ärik, Kzk. örik, Krg. örük, Özb. örik, Tkm. erik kelimeleri hâlâ kayısı anlamında kullanılır (Ercilasun vd., 1991: 458, 459). Türkiye Türkçesi ağızlarında da kelimenin erik, eruk, erük şekilleri kayısı manasında karşımıza çıkmaktadır (DS V, XII, 1993: 1778, 4497).

Türkler tarafından erken çağlardan beri tanınan erik, Yunus Emre’nin “Çıkdum erik dalına anda yidüm üzümi/Bostan ıssı kakıdı dir ne yirsün kozumı” (Erik dalına çıkıp orada üzüm yedim, bostan sahibi “niçin cevizimi yiyorsun?” diye azarladı) beytiyle başlayan şiirinde önemli bir tasavufî unsur olarak karşımıza çıkar. Niyazî Mısrî beytin şerhini şu şekilde yapar: "Her işin kendine mahsus bir semeresi vardır. Tabiatta her meyvenin kendi ağacında yetişmesi gibi. (...) Yunus, erik ile şeriata, üzüm ile tarikata ve ceviz ile hakikate işaret etmiştir. Zira dışı yenip çekirdeği yenmeyen erik, amelin zahirine misaldir. Üzüm ise amelin bâtınına misaldir ki hem bütünüyle yenir ve hem de ondan reçel, pekmez, turşu, sirke ve daha değişik nice nimetler elde edilir. Üzümün bâtın ilmine misal olması içinde küçük de olsa çekirdekleri bulunması sebebiyledir ki bâtın ilminde dahi riya ve sem'a ve kendini beğenmişlik ve kusurlardan temizlenme zarureti vardır. İçinde asla yabana atılacak bir şey bulunmayan, hem yenen ve hem nice hastalık ve kusurlara şifa taşıyan Hindistan cevizi ise hakikate misaldir. İmdi, eriği erik ağacından, üzümü bağdan ve cevizi de ceviz ağacından talep etmek gerekir. Üzümü erik ağacında arayan, boş yere zahmet çeken bir ahmaktır; emeği boşa gider, mahsulü ise zahmetten ibarettir” (Ak, 2017: 13, 14).

Atasözlerine baktığımızda erik ağacı ile ilgili olumsuz bir imajın olduğunu görmekteyiz. Erik, farklı iklim koşullarında rahatlıkla yetişebilen bir ağaçtır. Toprak seçiciliğinin fazla olmaması, büyümesi için özel bir çaba gerektirmemesi, düşen bir çekirdekten hemen filizlenebilmesi gibi özellikleri onu Anadolu insanının gözünde alelade bir ağaç hâline getirmiştir. Dolayısıyla insanoğlu bahçesinde hemen her yerde kolaylıkla yetişip çoğalan bu ağaç yerine özel ilgi gerektiren, daha kıymetli gördüğü ürünleri yetiştirme gereği duymuştur. Bu durum atasözlerine "bağına erik, evine (köyüne) yörük koyma (sokma)", "bahçene erik, evine yörük”, "evine yörük, bağına erik bastırma” şeklinde yansımıştır. Söz konusu örneklerde, göçebe yaşam tarzına sahip yörüklere karşı olumsuz bakış açısı da görülmektedir.

Erik, aynı zamanda gevrek yapısı nedeniyle dalları çabuk kırılan bir ağaçtır. "Erik dalına basma, her söze kulak asma” atasözünde söylenen her sözün ciddiye alınmaması gerektiği vurgulanır. Erik dalının bu durumu Burdur Dirmil yöresine özgü olduğu tescillenen "Erik Dalı” türküsünün "Erik dalı gevrektir/Amanın basmaya gelmez" dizelerinde de karşımıza çıkmaktadır.

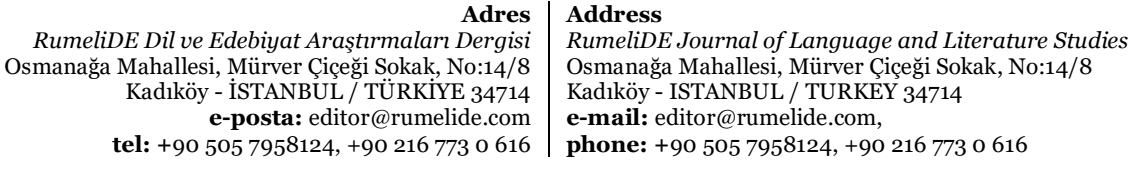




\section{Gül}

Gül için "1. Gül ağacının güzel kokulu, pek çok çeşidi bulunan çok makbul çiçeği, 2. Gül ağacı" tanımları yapılır (Ayverdi, 2011: 1123). Türk dünyasında eski devirlerden beri bilinen ve çokça kullanılan gül, çağdaş lehçelerde şu şekillerde karşımıza çıkar: Azr. gızılgül, Kzk. ravşan, Krg., Tat. roza, Özb. ätirgül, YUyg. gül, kızıl gül (Ercilasun vd., 1991: 290, 291). Farsçada genel olarak "çiçek” manasına gelen kelime ( $g u l$ ), dilimizde daha çok belli bir türü karşılamaktır.

Türk kültürünün önemli motiflerinden biri olan gül, edebiyatımızın sözlü ve yazılı ürünlerinde bir ağaçtan ziyade hoş kokulu, güzel renkli, baharda açan çiçeği ile ön plana çıkar. Gülün, dîvan edebiyatında ayrıcalıklı bir yeri vardır. Gül, sevgili tipinin bütün özelliklerini taşır ve güzellik yönünden sevgiliyle karşılaştırılır. Tazelik, incelik, narinlik, nazlılık hem gülün hem de fidanının, dalının, yaprağının özelliğidir ve bunlar sevgilinin boyunu, yüzünü, yanağını ifade etmektedir. Gülün dikeni âşığın rakibidir. Aynı zamanda gül ile diken iyilik/kötülük, kolay/zor, dost/düşman gibi zitlıkların sembolüdür. Bütün klasik Doğu edebiyatlarında olduğu gibi dîvan edebiyatında da gül ile bülbülün aşkı anlatılmakta, gül ile bülbül sevgiliyi ve âşığı temsil etmektedir. (Kurnaz, 1996: 220).

Rengi, şekli ve kokusu dolayısıyla çeşitli benzetmelere konu olan gül, öncelikle Hz. Muhammed'e benzetilmektedir. Yunus Emre'nin "Çiçek eydür ey derviş gül Muhammed teridir" dizesinde bahsettiği üzere gülün kokusunu Hz. Muhammed’in terinden aldığına inanılır. Halk arasındaki "gül koklamak sevaptır” inanışı da gülün Hz. Peygamber’in sembolü olmasından ileri gelir (Kurnaz, 1996: 220). Gül, tasavvufi düşüncede ilahî güzelliğin ve Hz. Peygamberin sembolü olmasının yanı sıra başka anlamlar da taşımaktadır. Gonca hâlindeki gül vahdeti/tekliği, açılmış gül ise kesreti/çokluğu temsil eder. Bir başka açıdan gül, kısa ömürlü oluşu nedeniyle hayatın geçiciliğini ifade etmektedir. Yine tasavvufi sembolizmde servi vahdeti, gül kesreti temsil etmekte olup kesret içindeki vahdeti ifade etmek için "serv-i gül endâm" tabiri kullanılmaktadır (Bardakcı, 2010: 109, 110).

Çeşitli yönleriyle edebiyatımızın her alanında karşımıza çıkan gül, atasözlerinde daha çok odunu, yetişme koşulları, kısalığı ve güzel kokusuyla yer alır. "Gül dalından odun, beslemeden (çingeneden) kadın olmaz", ve "halayıktan (beslemeden) kadın olmaz, gül ağacından odun (olmaz)" örneklerinde her şeyin niteliklerine göre değerlendirilip uygun amaçla kullanılması gerektiği vurgulanır. Gülün, çalı formunda, ince dallı oluşu nedeniyle odun olarak kullanılması uygun görülmediği gibi hizmetçi olarak yetişmiş biri de kültürlü biri için uygun eş olarak görülmemektedir.

Bütün canlıların hayatlarını devam ettirebilmesi için kendilerine uygun ortam ve şartlara ihtiyacı vardır. Bu ortamın sağlanamadığı durumlarda yaşamın sürdürülemeyeceği "dağ gülü bağda bitmez, bağ gülü dağda bitmez" atasözü ile anlatılmaktadır. İyi insanların yanında yetişenlerin de iyi olacağı "gülün dibinde gül biter" denilerek vurgulanmıştır. Birkaç metre boylanabilen ve güzel kokulu olan gül ağacı, kâinattaki her şeyin kendine has iyi ve kötü yanları olduğunun anlatıldığı "gül güdük amma kokusu güzel, selvi uzun (büyük) amma yapısı güzel”, "kavak uzun dipisi (tipisi) çok, gül kısa kokusu çok” atasözlerinde yer almıştır.

Gül ile bülbülün birlikte anıldı̆̆ı örneklere atasözlerinde de rastlarız. "Bülbülle gezen güle, ördekle gezen göle gider", "bülbülle konuşan güle, kargayla konuşan küllüğe”, "karga ile görüşen çöplüğe, bülbülle görüşen güle gider" atasözlerinde kişinin kimin yanında olursa, kimle arkadaşlık ederse etkilenip onun gibi olmaya başlayacağı vurgulanmıştır.

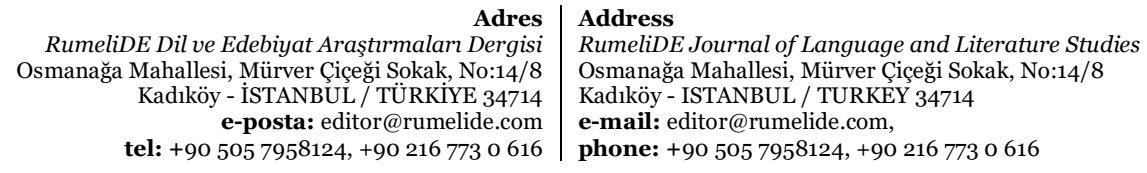




\section{İncir}

İncir için "süt taşıyan ve kışın yaprağını döken ağaç veya ağaççık. Türkiye'de yabani olarak yetiştiği gibi meyvesi için özel olarak da yetiştirilmektedir" der Baytop (2007: 143). İncir ağacının ana yurdu Ön Asya Sami ülkeleri Suriye ve Filistin olup en tatlı meyvelerini buralarda vermiştir (Hehn, 2003: 65). İncir kelimesi ile incir meyvesini Türkler Anadolu’ya gelmeden öğrenmiştir (Ögel, 1978: 304). Eski Uygurca yazma ve belgelerin söz varlığını içeren Uigurisches Wörterbuch’ta äncir maddesini görürüz. Röhrborn kelimenin Soğdça olduğu bilgisini verirken (1998: 379) bazı kaynaklarda kelimenin Farsça enciríden alıntı olduğu belirtilir (TDK, 2019: 1190; Ayverdi, 2011: 426; Eren, 1999: 191). Harezm Türkçesi eserlerinden Kısasü’l-Enbiyấ'da incir yıg்açı şeklinde gördüğümüz incir ağacının Hz. Adem'e beş yaprak verdiği için Tanrı tarafından mükâfatlandırıldığından ve incirin hem dışının hem de içinin yenildiğinden bahsedilmektedir: "İncir yıġaçı Ādem ve Ḥavvaġa béş yapurğaḳ bérdi, endāmların örtüp çıḳtılar, tā [Tenri] aytmışdan kédin ol béş yapurgakạdan birin keyik yédi yıpar boldı, birin balık yédi anber boldı, birin aru yédi 'asel boldı, birin ḳurt yédi yipek boldı, birin Ādem yérge tikdi yün boldı ḳıyāmetğa tegi oğlanlarınġa küç boldı. Nükte: İncir yıġaçı Ādemġa yapurgak bérmişi üçün Tenri 'azze ve celle beḍerledi. Kamug yémiş üç türlüg turur kiminin tışı yénür alma, armūd menizlig, kiminin içi yénür tı̧̧ı yénmez yanaḳ, bādām menizlig kiminin taşı ma yénmez içi ma yénmez ḳag̉un, harpuz menizlig. Ammā incirnin taşı hem yénür içi hem yénür" (Ata, 1997: 18, 19). Kıpçak Türkçesi sözlüğü Kitâbü’l-İdrâk’ta incir anlamında ilek kelimesi geçer (Caferoğlu, 1931: 38). Batı Anadolu ağızlarında erkek veya baba incir yerine ilek, ĭglek denildiğini görürüz (DS VII, 1993: 2510, 2519). İncir ağacının meyvesine ülkemizin pek çok yerinde ballıdarı ve yemiş de denilmektedir (DS II, XI, 1993: 510, 4242).

Geçmişi insanlık tarihi kadar eski olan incirden kutsal kitapların hemen hepsinde söz edilir (Anaç, 2012: 17). Kur'an-ı Kerim'de Arapça incir anlamına gelen tîn kelimesinden adını alan surede incire ve zeytine yemin edilmektedir (Tîn 95/1 "Yemin olsun incire ve zeytine"). Meyvesi, sütü, yaprağıyla incir ağacına bütün kültürlerde mit dünyasından günümüze kutsallık, varlık, güç, bilgelik, verimlilik, bolluk bereket, doğurganlık gibi semboller yüklenmiştir (Koçak, 2011: 283-285). İncir ağacına yüklenen olumlu sembollere karşın olumsuz imaja da rastlarız. Günümüzde sıklıkla kullanılan "ocağına incir ağacı dikmek” deyimi bunun en yaygın örneğidir. Anadolu’da halk arasında incir ağacının altında uyuyanları şeytanın alıp götüreceği, incir ağacından düşenin iflah olmayacağı, incir ağacının altında yatmanın uğursuzluk getireceği gibi inanışlar yaygındır (Koçak, 2011: 285-286).

İncir ağacının odunu yaşken süngerimsi, kolay kırılan ve eğrilen bir odundur. İyice kuruduktan sonra ise meşe odunu kadar sert olur ve asla kırılmaz. Bu nedenle incir odunu "işe yaramaz odun" olarak anılır. "İncir (odunu) gibi işe yaramaz herif” şeklindeki ifadeler buradan gelmektedir (Hehn, 2003: 69). İncir odununun bu özelliği nedeniyle kötü malzemeyle iyi bir iş yapılmaz manasında "darı unundan baklava, incir ağacindan oklava olmaz" denilmektedir.

İncirin gelişmesi ve yayılması zeytin ile birlikte incelenir (Ögel, 1978: 303). Zeytin ağacıyla incir ağacı aynı dönemde meyve verir. Zeytin sineğinin zeytin ağacına ve meyvesine zarar vereceği dönemde olgunlaşan incirler bal dökmeye başlar. İncirin balı zeytin sineklerini üstüne çeker ve balı yiyen sinekler bir süre sonra zehirlenerek ölür (https://www.tarimtv.gov.tr/tr/video-detay/zeytin-sinegi-zararlisinaincir-agacli-koruma-10489). Bir atasözünde de incir ve zeytinin yetişme süreleri dolayısıyla birlikte verildiğini görürüz. Ülkemizde genellikle çelikleme yöntemiyle üretilen incir ağaçları, dikimlerinden 45 yıl sonra yılda ortalama 5-6 kg ürün verir. 9-10 senelik ağaçlardan yılda ortalama $20 \mathrm{~kg}$ ürün alınırken 25-30 yıllık ağaçlarda bu sayı yaklaşık 45-50 kilograma ulaşır (Günal, 2008: 567). "İncir babadan, zeytin

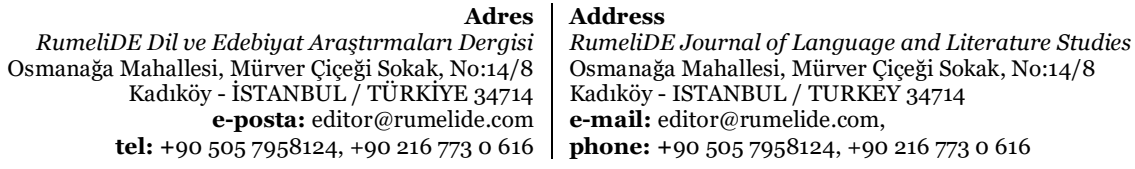


dededen", "zeytin dededen, incir babadan kalmalı" atasözlerinde incir ağacının bol ürün verebilmesi için bir kuşak geçmesi gerekirken zeytin için en azından iki kuşaklık bir zaman geçmesi gerektiği vurgulanır.

Atasözlerinde halk takviminin yansımalarını da sıklıkla görürüz. Uzun süreli gözlemler sonucu edinilen bilgiler, tecrübeler halk takvimini oluşturur. Ağızlarda karşımıza çıkan "incir yaprağı deve tabanı kadar olmayınca yaz gelmez” atasözünde de halkın incir yaprağının boyutuna bakarak yaz mevsiminin başlaması ile ilgili gözlemine ulaşırız.

\section{Kavak}

Kubbealtı'nda kavak, "söğütgillerden, sulak yerlerde yetişen, yaprakları uzun saplı ve dişli, boyu düzgün ve bazı türlerinde 30-40 metreyi bulan uzunlukta, kerestesi için dikilen, odunu gevşek ve kof, kabuğu kavlayıp dökülen bir ağaç (Populus)" diye tanımlanır (Ayverdi, 2011: 1629). Bazı türlerine ak kavak, akça kavak, Fırat kavağı, tuzcul kavak, kara kavak, dağ kavağı, titrek kavak gibi adlar verilir (Baytop, 2007: 162). Eren, sözcüğün Türkçe kav kökünden $k a v+(a) k$ şeklinde türediğini ve kabuğu döküldüğü, kavladığı için bu adın verildiğini belirtir (1999: 219). Tarihî metinlere baktığımızda Dîvânu Lugâti’tTürk'te tirek "kavak ağacı", tograk "karakavak" (Ercilasun, Akkoyunlu, 2015: 178, 204), Kipçak dönemi sözlüklerinden Kitâb-ı Mecmû-ı Tercümân-ı Türkî ve Acemî ve Mugalî'de avsaḳ "kavak ağacı" kelimelerini görürüz (Toparlı vd., 2014: 16). Çağdaş lehçelerde kavak, Azr. govag, Bşk., Tat. tiräk, Kzk., Krg. terek, Özb., YUyg. teräk, Tkm. derek (ă̆aç) olarak görülmektedir (Ercilasun vd., 1991: 454, 455).

Türk mitolojisinde önemli bir yere sahip olan kavağın en önemli fonksiyonu göğün direği ve dünya ağacı olmasıdır (Ergun, 2004: 216). Bir Altay destanında yer altı, yeryüzü ve gökyüzünü birleştiren ağaç, kavak ağacı (Bay Terek) olarak anlatılmaktadır (Ergun, 2004: 218). Manas Destanı'nda kavak, ölüm ve dirilme sembolü olarak karşımıza çıkar. Uzun ve düzgün yapısıyla dikkat çeken kavak ağacı için Teleüt Türkleri “terekten yüksek ağaç yoktur” demişlerdir (Ögel, 1995: 474, 475).

Kavak, atasözlerinde daha çok uzun yapısıyla karşımıza çıkar. Her ilerleyişin bir sınırı vardır anlamında "kavak uzaya uzaya göğe ermez (çlkmaz)", "kavak uzaya uzaya göğe değmez ya, elbet bir gün belinden kırlır" denilmiştir. "Her uzun ağaç kavak değildir" denilerek dış görünüşe aldanmamanın gerekliliği anlatılmıştır. Sağa sola fazla dallanıp budaklanmadan göğe doğru yükselen bu ağacın gölgesi azdır. "Kavak da uzun; fakat gölgesinde oturulmaz" atasözüyle fiziksel büyüklükten ziyade işe yaramanın önemli olduğuna dikkat çekilir. Tanrı bir kimsenin zengin olmasını isterse ona beklemediği yerlerden gelir kapısı açar anlamında "Allah verirse Tepelioğlu'nun kavağında da verir"6 denilmektedir.

Kavak, odununun gevşek ve kof olmasıyla da atasözlerinde yer alır. Kavak odunu çabuk yanar, ssıtmaz ve tüter. Bu sebeple "kavak ağacından odun, halayıktan kadın (olmaz)" denilmiştir. "Kavak, yaprağını tepeden dökerse kış çok olur” atasözünde halk takviminin izleri görülür. Halk arasında kavak ağacının yaprakları tepeden dökülmeye başlarsa o yıl kışın sert geçeceğine inanılmaktadır. "Meşe gibi dikilmesini değil, kavak gibi eğilmesini bilmeli” örneğinde körü körüne inat etmemenin gerektiği öğütlenir. Kişiyi güçlü yapan ailesi, akrabaları, yakınlarıdır anlamında "kavak dalıyla gürler" denilmiştir. Gerçekleşmesi mümkün olmayan durumlar için söylenen "balık kavağa çıtığı vakit kösenin de sakalı biter" atasözü mevcuttur. Bazı araştırmacılar burada bahsedilen kavağın ağaçla ilgisi olmadığını, söz konusu kavağın İstanbul Boğazı'nın Karadeniz’e açılan noktasında yer alan Anadolu Kavağı ve Rumeli Kavağı semtleri olduğunu belirtir (Yund, 1944: 35; Pala, 2020: 39). Buralar çok rüzgârlı ve akıntılı olduğu için balıkçılar

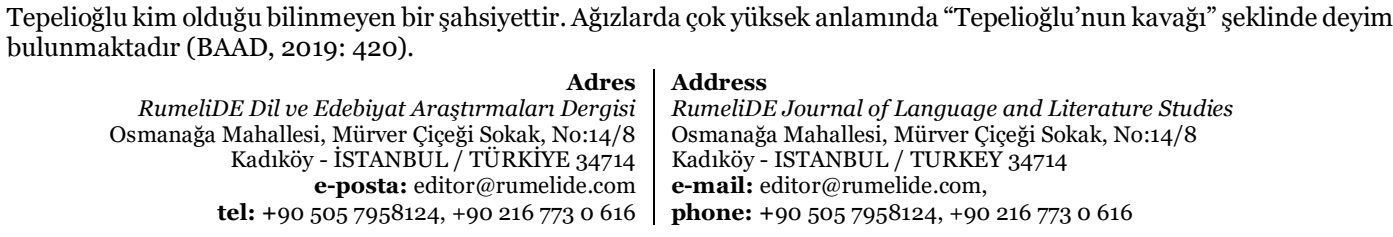


avlanamaz. Pala’ya göre İstanbul civarında türetilen "balık kavağa çıkınca" deyimi diğer şehirlere yayılınca İstanbul'daki bu semtleri bilmeyenler tarafından yer adı olan Kavak, kavak ağacı ile ilişkilendirilmiştir (2020: 39).

Kavak, kökünün sığ oluşu ve uzunluğu nedeniyle en hafif rüzgârdan bile etkilenip eğilen, yaprakları âdeta ıslık çalar gibi hışırdayan bir ağaçtır. Bir atasözünde "kavak uzun dipisi çok, gül kısa kokusu çok" denilmektedir. "Kavak başında yel olur, gurbete çıkan del' olur”, "köyden çıkan deli olur, kavak başında yel olur", "memleketinden çıan deli olur, başında kavak yeli olur” örneklerinde doğup büyüdüğü yeri terk edip başka yere göç edenlerin durumuna değinilmiştir. Kavak-yel ilişkisi atasözlerimizde olduğu gibi deyimlerimizde de yer bulur. Günümüzde yaygın şekilde kullanılan "başında kavak yeli (yelleri) esmek"7 deyimi bazen bir gencin sorumluluklarından uzak bir şekilde zevk ve eğlence peşinde koşması bazen de insanların gerçekleşmeyecek şeylerin hayaliyle vakit öldürmesi manasında kullanılır. Kendini bir dönem zevk ve eğlenceye kaptırmamış genç yoktur anlamında kullanılan "başını sallamayan (sallamadık) kavak (ağaç) olmaz” atasözü de kavağın insanı işaret ettiği örneklerden biridir.

Yukarıda saydığımız örneklerin dışında, ağızlarda “- Kavakta nar biter mi? - Kafan kadar", "körden, savaktan, meyvesi bitmedik kavaktan sakın” şeklinde atasözleri de bulunmaktadır.

\section{Meşe}

Meşe, "kayıngillerden, ak meşe, kara ve kızl meşe, mantar meşesi, palamut meşesi, mazı, yer meşesi gibi pek çok türü olan, dayanıklı, uzun ömürlü, gösterişli orman ağacı (Quercus)" diye geçer (Ayverdi, 2011: 2058). Kelime, Azr. palıd, Bşk., Tat. imän, Kzk., Krg. emen, Özb., YUyg., emän, Tkm. dub şeklinde görülür (Ercilasun vd., 1991: 584, 585).

Meşe, Farsça biş̧e'den $b>m$ değişikliği yoluyla mişe $>$ meşe şeklinde dilimize girmiştir. Farsçada "orman" anlamına gelen kelime, dilimizde de başlangıçta aynı anlamda kullanılırken sonradan "meşe ağacı" anlamını kazanmıştır (Eren, 2001: 686). Karahanlı dönemi eserlerinden Atebetül-Hakayık'ta biş̧e "orman, ağaçlık" manasında karşımıza çıkar (Arat, 1951: XI). Meninski “Quercetum 'mişselik, mişse, biş̧e, ormān, tīmās'; Quercus 'belūt ag̉acı, mişe/meşe, sendiyān”" şeklinde açıklama yapar (Meninski, 1687: 1422).

Türk dünyasında heybetli gövdesiyle dikkat çeken meşeye, özellikle Çuvaşlar ayrı bir önem vermiştir. "İhtiyar meşe bizim babamızdır" diyen Çuvaşlar için meşe, ormanın hükümdarıdır. Meşe, bir kahraman gibi güçlüdür ve erkeğin de onun gibi sağlıkll, koruyucu, sorumluluk sahibi olması beklenir (Ergun, 2004: 236).

Dilimizde meşe ağacı anlamında pelit (Ar. bellūt) kelimesi de kullanılmaktadır. Ağızlarda "dağ başında çam kadı, pelit müftü” atasözüne rastlarız. Şehirden uzakta, kanun ve nizamın yeterli olmadığı yerlerde yaşayanların çaresizliklerinin anlatıldığı sözde, ormanların görkemli ağaçlarından pelit ile din işlerine bakan müftü sembolize edilmiştir. Meşe, ağızlarda orman anlamında da karşımıza çıar (https://sozluk.gov.tr/). "Meşe aslansız olmaz", "meşe çakalsız olmaz" atasözleri bunun örneklerindendir. Bu atasözlerinde meşe, topluma işaret ediyor olup her toplumda aslan gibi cesur ya da çakal gibi kurnaz kişilerin olduğuna dikkat çekilmektedir. Bir aileden iyi de kötü de birilerinin çlkabileceği "bir meşeden okluk da çıkar bokluk da" atasözüyle anlatılmıştır. Sıradan biri kendisinden

Pala, söz konusu kavak yelinin Anadolu Kavağı ile Rumeli Kavă̆ı’nda esen şiddetli rüzgârlar olduğunu belirtir (2020: 39).

Adres Address

RumeliDE Dil ve Edebiyat Araştırmaları Dergisi $\quad$ RumeliDE Journal of Language and Literature Studies

Osmanağa Mahallesi, Mürver Ciçeği Sokak, No:14/8 $\quad$ Osmanağa Mahallesi, Mürver Çiçeği Sokak, No:14/8

Kadıköy - İSTANBUL / TÜRKIYE 34714 Kadıköy - ISTANBUL / TURKEY 34714

e-posta: editor@rumelide.com $\quad$ e-mail: editor@rumelide.com,

tel: +90 505 7958124, +90 216773 o 616 phone: +90 505 7958124, +90 216773 o 616 
üst düzeyde birine küsüp darılsa bunun o kişinin umrunda bile olmayacağ "ayı meşeden küsmüş, meşenin haberi yok" şeklinde söylenmiştir.

Meşenin yaz kış yapraklarını dökmeyen, küçük ve çiğnenebilir yapraklı cinsleri keçiler için cezbedici bir besin kaynağıdır. Ancak keçiler, ağaçların filizlerini, yapraklarını, genç fidanları yiyerek onlara zarar vermekte, hatta kurumasına neden olmaktadır. İçindeki tanen miktarı nedeniyle meşe kabuğu ve meşe palamudu deri tabaklama işleminde sıklıkla kullanılır. Aynı şekilde sumak yapră̆ından da dericilikte faydalanılmaktadır. Arka planda bu gerçekliğin yattı̆̆ "keçinin meşeye ettiğini külü derisinden çıkarır" ve "keçinin sumağa (meşeye) ettiğini sumak keçiye edecek" atasözlerinde kötülük eden kötülük bulur mesajı verilmektedir. Meşe, sert bir ağaçtır ve onu eğip bükmek kolay değildir. Onun bu özelliği "meşe gibi dikilmesini değil, kavak gibi eğilmesini bilmeli” atasözüne yansımıştır. Büyükleri eğitmenin zor olduğu, eğitimin çocuk yaşta verilmesi gerektiği “(kuru ağaç eğilmez), kart meşe bükülmez” şeklinde öğütlenmiştir.

Ağızlarda kalın gövdeli meşe ağacına kabaağaç denildiğini de görmekteyiz (DS VIII 1993: 2577). Tembel kişilerin sürekli rahatlarının peşinde oldukları "kızıl tembel, yazın koyu kabaağaç gölgesi arar" sözüyle dile getirilmiştir.

\section{Servi/Selvi}

Servi, "servigillerden, kışın koyu yeşil yapraklarını dökmeyen, daha çok mezarlıklara dikilen, uzun ömürlü, güzel kokulu, ince uzun ağaç (Cupressus)” diye tanımlanır (Ayverdi, 2011: 2788). Kelime, Farsça serv'den ses türemesi ile oluşmuş ve $r$ - $l$ değişikliği ile selvi şeklini almıştır. Halk arasında daha çok selvi olarak bilinir. Çağdaş lehçelerde Azr., Özb., YUyg. särv, Bşk. särbi ă̆ası, kiparis, Kzk., Krg. kiparis, Tat. särbi ă̆açı, kiparis, Tkm. servi şeklinde geçer (Ercilasun vd., 1991: 764, 765).

Genellikle mezarlara dikilen servi, Türk kültüründe uzun olması ve daima yeşil kalmasıyla ebediyeti sembolize eder. Sürekli yeşil olmaları, ata ruhlarının cennette olduğunun kanıtı ve ölen ataların torunlarının mutlu yaşamalarının sembolüdür. Ata ruhları bu ağaçlar sayesinde göğe ulaşmakta ve Tanrı'nın kutu aşağıya, kemiklere inmektedir (Ergun, 2004: 234).

Dîvan şiirinde adı en çok geçen ağaç, servidir. En dikkat çekici özelliği ise uzun ve düzgün olmasıdır. Servi, sevgilinin boyu için hem benzeyen hem de benzetilendir. Hafif rüzgârla salınışı sevgilinin yürüyüşünü andırır ve sevgili için serv-i revân tamlaması kullanılır. Rüzgâr ile salınırken "Hû" (Allah!) sesini çıkarması dolayısıyla mezarlıklarda çok bulunur. Bu durum onun Allah’ı zikrettiğine yorumlanır ve mezarlıktaki ölüler için bir mağrifet vesilesi olarak düşünülür (Pala, 2002: 414).

“Gidelim serv-i revânım yürü Sa 'dâbâd'a” (Nedîm, M. 40)

Tasavvufta da servi, dalsız budaksız, düz bir ağaç oluşu nedeniyle Arap alfabesinin ilk harfi elife ve bir rakamına benzetilir. Bu özelliğiyle de adeta Allah’ı sembolize eder (Cebecioğlu, 2004: 561).

Selvi, atasözlerinde de uzun ve düzgün yapısıyla yer alır. "Gül güdük amma kokusu güzel, selvi uzun (büyük) amma yapısı güzel” örneğinde, evrendeki her şeyin kendine has iyi ve kötü yanlarının bulunduğu, onları birbirleriyle mukayese etmenin, birini diğerinden üstün tutmanın doğru olmadığ anlatılır. "Her uzun ağaç selvi değildir" atasözüyle de dış görünüşe aldanmamanın gerekliliği öğütlenmektedir.

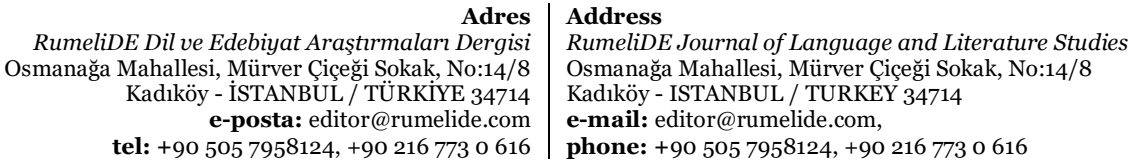




\section{Söğüt}

Söğüt, "söğütgiller familyasından, daha çok su kenarlarında yetişen, pek çok çeşidi olan, uzun ve acı yaprakll, kabuğu kolay soyulur bir ağaç (Salix)” şeklinde tanımlanır (Ayverdi, 2011: 2871). Eski Uygur Türkçesinden itibaren görmeye başladığımız sögüt, Uygurcada genel anlamda "ağaç" olarak geçmektedir. Borlukta tegm[i]şte borlukç̧ı erke inçe tip tidi ḳaç k[elreklig yimişs sögütī üze birer çı)ratg்u ası̄ “Bağa varınca bağcıya şöyle dedi: Her bir meyve ağacının üzerine birer çan asın” (Tulum, Azılı, 2015: 150, 151). Kelime, Karahanlı Türkçesinde "söğüt ağacı" manasında kullanılmaya başlar (Clauson, 1972: 819).

Azr. söyüd, Bşk., Tat. tal, öyägki, Kzk. tal, Krg. tal, sögöt, Özb. tàl, Tkm. sövüt, YUyg. sögät (Ercilasun vd., 1991: 792, 793) şeklinde geçen söğüt ağacıyla ilgili Türk dünyasında çeşitli inanışlar mevcuttur. Sahalar söğüdü ruhlu ağaç olarak kabul ederler. Küçük kuşlar söğüde yuva yapmayı sever. Böylece söğüde annelik kutu siner. Söğüdün kutu insana girdiğinde de insan, duygulu, çocuk sever ve evcimen olur (Yıldırım, 2000: 416). Yerli bir ağaç olan söğüt, daima evin önündedir. Eve faydası olacağına, ailenin sıkıntılarını çözeceğine inanılır (Ergun, 2004: 240, 241). Türk coğrafyasında ağaçlarla ilgili çok fazla yer adı bulunmaktadır. Anadolu'da da Söğüt, Osmanlı beyliğinin ilk başkenti olarak bilinir.

Klasik edebiyatta söğüt ağacından bahsedilen beyitlerin çoğunda Farsça bîd kelimesi tercih edilmiştir. Söğüt, su kenarında olması ve yapraklarının titreyişi bakımından teşbihlere konu olmuştur (Pala, 2002: 82).

Böyle bî-hâlet değildi gördüğüm sahrâ-yı aşk

Anda mecnûn bîdler dîvâne cûlar var idi

(Nedîm, G. 147-2)

Söğüt ağacı, atasözlerinde gölgesi ve doğal özellikleriyle öne çıkar. Atalarımız, "koz gölgesi kız gölgesi, söğüt gölgesi yiğit gölgesi, dut gölgesi it gölgesi” demiştir. "Ceviz gölgesi yavuz gölgesi, söğüt gölgesi yiğit gölgesi”, "ardıç gölgesi kardeş gölgesi; söğüt gölgesi yiğit gölgesi” şekilleri de mevcuttur. Söğüdün çok büyüyüp gelişebilen türleri vardır. Sarkan dalları ve yaprakları hafif bir rüzgârda yelpaze görevi üstleneceğinden gölgesinde huzurla vakit geçirilebilir. Söğüt, odunu hafif ağaçlardan olsa da ince, uzun dalları ile hacimce geniş bir yer kaplar. "Ağaçlardan söğüttür en kabası, yiğidi hor gösteren eğnindeki abası” atasözünde söğüdün şekline temas edilmiştir. Söğüt, suyu da çok seven ağaçlardandır. Ağızlarda "söğüt (dut) suda dura dura olur abanız, çoban kapıda kala kala olur babamız" şeklinde bir atasözü görülmektedir.

Söğüt, aynı zamanda ilkbaharda arıların bal kaynaklarından biridir. Arılar söğüt ağacından propolis denen yapışkan bir madde alır ve onu kovan içerisinde delik ve çatlakların kapatılması, peteklerin tamir edilmesi, kovan girişini daraltma gibi amaçlarla kullanır (Kumova vd., 2002: 10, 11). Ayrıca kaliteli bal için söğüt dallarından kovan örülür. Herkes işine yarayan şeyi benimser anlamında "arı söğüdü, akıllı öğ̈̈dü sever” denilmektedir. Yumuşak ağaçlardan biri olan söğüt çabuk yanıp geçer, arkasında köz bırakmaz. Bu özelliğiyle de "tavuk să̆ılmaz, söğüt yakılmaz, güveye güvenilmez", "söğüdün közü, kadının sözü” atasözlerinde yer bulmuştur.

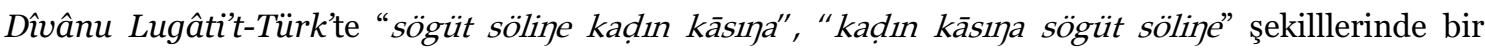
atasözü yer alır. Kaşgarlı bunu "söğüde tazelik, taravet yakışır; kayın ağacına kartlık yakışır. Aslına çeken şeyler için kullanılı»” şeklinde açıklar (Ercilasun, Akkoyunlu, 2015: 153). Sözlüğün başka bir sayfasında aynı atasözü için "söğüt ağacının nemi kendisine yakışır, bir ağaç türü olan kayının da katı kabuğu kendisine yakışır” denir (Ercilasun, Akkoyunlu, 2015: 402). Kayın, söğüt ağacına göre çok daha yavaş

Adres | Address

RumeliDE Dil ve Edebiyat Araşturmalar Dergisi $\quad$ RumeliDE Journal of Language and Literature Studies Osmanağa Mahallesi, Mürver Çiçeği Sokak, No:14/8 Osmanağa Mahallesi, Mürver Çiçeği Sokak, No:14/8 Kadıköy - İSTANBUL / TÜRKIYE 34714 Kadıköy - ISTANBUL / TURKEY 34714 e-posta: editor@rumelide.com e-mail: editor@rumelide.com, tel: +90 505 7958124, +90 2167730616 phone: +90 505 7958124, +90 2167730616 
büyüyen ve çok daha uzun ömürlü olan bir ağaçtır. Albayrak, "söğüde tazelik, kayın ağacına kartlık yakışır" atasözü için "bazı şeylerin taze ve genç olanı, bazılarının da yıllanmış, yaşlanmış olanı güzeldir" yorumunda bulunur (2009 :796). Söğüt ağacı ile ilgili başka bir atasözü Dîvânu Lugâti’t-Türk’te "köp sögütke kuş konar körklüg kişike söz kelir" şeklinde gördüğümüz "gür (çok) söğüde kuş konar, gösterişli kişiye (güzele) söz gelir"dir. Kaşgarlı bunu "kuş, gür ve dolaşı dallı söğüt ağacına konar; güzel ve aydınlık yüzlü kadına söz gelir” diye açıklar (Ercilasun, Akkoyunlu, 2015: 140).

\section{Zeytin}

Türkçe Sözlük’te zeytin, "zeytingillerden, Akdeniz ülkelerinde yetişen, 10-20 metre yüksekliğinde, dalları dikensiz, yaprakları karşılıklı, küçük ve gümüş renginde, uzun ömürlü bir ağaç (Olea europaea)" olarak geçer (2019: 2653). Arapçadan (< zeytūn) dilimize giren kelimenin çağdaş lehçelerde şu şekilleri karşımıza çıkar: Azr. zeytun, Bşk., Kzk., Tat., zäytün, Krg. olifka, zeytun, Özb., YUyg. zäytun, Tkm. zeytūn (Ercilasun vd., 1991: 1014, 1015). Tarihî metinlere baktığımızda Karahanlı dönemi Kur'an tercümelerinden Rylands nüshasında kelimeyi zeyt yıg்açı "zeytin ağacı" (Nahl 16/11) şeklinde görürüz (Ata, 2013: 50). Harezm Türkçesi ile yazılmış Kısasü’l-Enbiyâ’ da Hz. Nuh kıssasının anlatıldığı bölümde haber getirmesi için gönderilen güvercin, gagasında zeytin ağacı yaprağıyla döner: "Téyürler: zeytūn yığaçının yapurğaḳını tumşuḳında alıp keldi Nūhgia körgüzdi” (Ata, 1997: 38). Kutsal kitaplarda zeytin sıklıkla zikredilmekte olup Kur'an-ı Kerim'de zeytine yemin edilmekte (Tîn 95/1) ve zeytin ağacı "mübarek" sıfatıla nitelendirilmektedir: "Allah göklerin ve yerin nûrudur. Onun nûrunun misali, içinde kandil bulunan bir kandilliktir. Kandil bir cam içindedir, cam inciyi andıran bir yıldızdrr; (bu kandil) doğuya da batıya da ait olmayan, yağı neredeyse ateş dokunmasa bile ışık veren mübarek bir zeytin ağacından yakılır. Nûr üstüne nûr. Allah nûruna dilediğini kavuşturur. Allah insanlar için misaller veriyor, Allah her şeyi hakkıyla bilmektedir" (Nûr 24/35). Ünsal, Tevrat ve İncil'de 140 kez zeytin sözcüğünün geçtiğinden bahseder (2019: 32).

Meyvesi, yağı, yaprağı, odunu ile hayatımızda önemli bir yer tutan zeytin ağacı zaferi ve barışı, bilgeliği, umudu, ışığı/nuru, bereketi, sağlı̆̆ , dengeyi simgeler (Aça, 2017: 257-267). Ortalama ömrü 300-400 yıl olup 1000 ylla kadar yaşayabilen zeytin ağacının bol ürün verebilmesi için iki kuşaklık bir zamana ihtiyacı vardır. Bu durum atasözlerine "bağ babadan, zeytin dededen kalmalı (kalır)", "incir babadan, zeytin dededen”, "zeytin dededen, incir babadan kalmalı" şeklinde yansımıştır.

\section{Diğer ağaçlar}

Yukarıda ayrı başlıklar hâlinde incelediğimiz atasözlerinde bazı türler müstakil olarak anılırken bazıları ise diğer türlerle birlikte verilmiştir. Armut, kayın, kızılıık diğer türlerle birlikte anılan ağaçlardır. Kestane ve sumak aynı atasözünde ceviz ve meşenin yerine kullanılan türlerdir. Bunlarla ilgili açıklamalar birlikte kullanıldıkları türler altında verildiğinden ayrı başlıklar açılmamıştır. Belirtilen türlerin dışında birer atasözünde ıhlamur, kiraz, öd ağacı ve zerdaliye rastlanır. Buna ilişkin örnekler; "ihlamurdan odun, beslemeden kadın olmaz", “al kiraz üstüne kar yağmış (yağar)”, “öd ağacından kaşık olur ama tarhana içilmez", "zerdaliden kaval olmaz, al zurnadan haberi”dir.

\section{Sonuç}

İnsanoğlu tabiatı gereği içinde yaşadığı doğa ile sıkı bir ilişki hâlinde olmuş, bitkilere özellikle de ağaçlara ayrı bir ilgi duymuştur. Bu ilgi edebiyatımızın sözlü ve yazılı bütün ürünlerine yansımış ve ağaç, önemli bir tabiat unsuru olarak atasözlerinde de yerini almıştır. Bu çalışmada, Türkiye Türkçesi

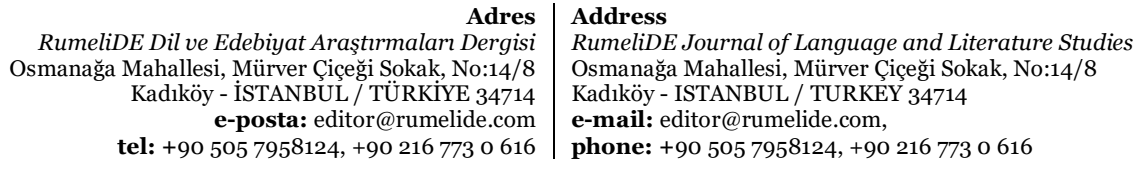


atasözlerinde geçen ağaç türleri taranmış ve ardıç, armut, asma, ceviz, çam, çınar, dut, elma, erik, gül, ıhlamur, incir, kavak, kayın, kestane, kızılcık, meşe, öd ağacı, selvi, söğüt, sumak, zerdali, zeytin olmak üzere toplam 24 tür tespit edilmiştir. Bu türler; gölgesi, odunu, yaprağı, meyvesi, boyu, kokusu, yetişme koşulu ve süresi gibi bitkisel ve fiziksel özellikleriyle bazen gerçek çoğu zaman da mecaz anlamlı atasözlerinde karşımıza çıkar. Atasözlerini incelediğimizde ağaç ve ağaç türlerinin çoğu zaman insana işaret ettiği görülmektedir. Tespit edilen ağaç türleri içerisinde kavak ve çamın geçtiği atasözleri diğerlerine göre daha fazladır. Ülkemizde pek çok türü yetişen, kerestesinden istifade edilen, uzunluğuyla da dikkat çeken kavak ve çam, bizim coğrafyamızda hep var olmuştur. Hayatın her safhasında çeşitli amaçlar için kullanılan, Türk kültüründe de bazı sembolik anlamlar yüklenen bu ağaçlar, doğal olarak atasözlerinde de sıkça yer almıştır. İncelediğimiz türlerde ceviz/koz, dut ve kavağa gölgesi; ardıç, çam, erik, gül, incir, kavak ve söğüde odunu dolayısıyla olumsuz bir bakış olsa da burada en dikkat çekici olan eriktir. Çünkü erik, atasözlerinde bağa bahçeye dikilmemesi öğütlenen bir ağaçtır. Hemen her yerde yetişebilen, bol sürgün veren, yetişmesi için özel bir çaba gerekmeyen bu ağacın Anadolu insanının gözünde pek bir kıymetinin olmadığı atasözlerinde görülmektedir.

Çalışmamızda, atasözlerinde geçen ağaç türlerinin çeşitli özellikleri, Türk dili ve kültüründeki yeri, gerçekten mecaza uzanan anlamları üzerinde durulmuş ve toplumun bu türlere bakışı ortaya konulmaya çalışılmıştır. Dolaylı anlatım ve söz sanatları kullanımı ile atasözlerinde geniş bir yer tutan ağaç ve türlerinin Türk kültüründeki önemine bir kez daha dikkat çekilmek istenmiştir.

\section{Kisaltmalar}

Alt. $\quad$ Altay Türkçesi

Azr. Azerbaycan Türkçesi

BAAD Bölge Ağızlarında Atasözleri ve Deyimler

Bşk. Başkurt Türkçesi

DLT Divânü Lûgat-it-Türk Tipkıbasımı

DS Derleme Sözlüğü

IrkB. Irk Bitig

KKlp. Karakalpak Türkçesi

Krg. Kırgız Türkçesi

Kzk. Kazak Türkçesi

Özb. Özbek Türkçesi

Tat. Tatar Türkçesi

Tel. Teleüt Türkçesi

Tkm. Türkmen Türkçesi

TT Türkische Turfan-Texte

Tuv. Tuva Türkçesi

YUyg. Yeni Uygur Türkçesi

\section{Kaynakça}

Aça, M. (2017). Zeytin Ağacı Simgesi. Emine Gürsoy Naskali (Ed.), Zeytin Kitabı (s. 255-269), İstanbul: Kitabevi.

Ak, S. (2017). Niyazî-i Mısrî, İsmail Hakkı Bursevî, Şeyhzâde, Çıktım Erik Dalına, Yunus Emre'nin Bir Şïrinin Üç Şerhi. İstanbul: Büyüyenay.

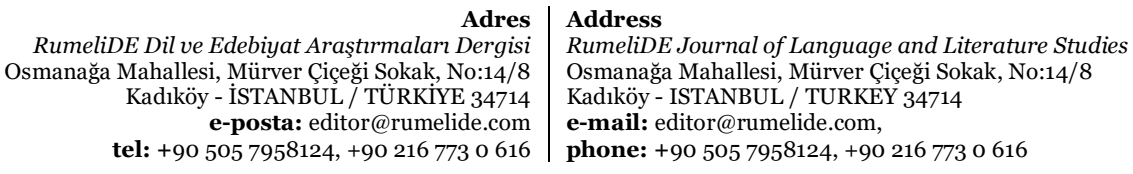


Aksoy, Ö. A. (2019). Atasözleri ve Deyimler Sözlüğü II, Deyimler Sözlüğü. İstanbul: İnkılâp Kitabevi. Aksoy, Ö. A. (2020). Atasözleri ve Deyimler Sözlüğü 1, Atasözleri Sözlüğü. İstanbul: İnkılâp Kitabevi. Albayrak, N. (2009). Türkiye Türkçesinde Atasözleri. İstanbul: Kapı.

Alptekin, A. B. (2007). Türk Halk Hikâyelerinde Ağaç Motifi Üzerine. Millî Folklor, 19 (76), 33-39.

Anaç, H. (2012). Geçmişten Günümüze İncir. Aydın: Aydın Ticaret Odası.

Anlı, R. E. (2006). Bağlar Güzeli Üzüm ve Üzüm Kültürü. İstanbul: Yapı Kredi Kültür Sanat.

Arat, R. R. (1951). Atebetü'l-Hakayık. İstanbul: Ateş Basımevi.

Arat, R. R. (1979). Kutadgu Bilig III İndeks. Kemal Eraslan, Osman Fikri Sertkaya, Nuri Yüce (Neşre haz.). İstanbul: Türk Kültürünü Araştırma Enstitüsü.

Arat, R. R. (1991). Eski Türk Şïri. Ankara: Türk Tarih Kurumu.

Arslan Erol, H. (2014). Eski Türkçeden Eski Anadolu Türkçesine Anlam Değişmeleri. Ankara: Türk Dil Kurumu.

Âşıkpaşaoğlu Âşıîi (1949). Osmanh Tarihleri I, Tevarih-i Âl-i Osman. (Haz. Çiftçioğlu N. Atsız). İstanbul: Türkiye Yayınevi.

Ata, A. (1997). Kısasü'l-Enbiyâ (Peygamber Kıssaları) I Giriş-Metin-Tıpkıbasım, II Dizin. Ankara: Türk Dil Kurumu.

Ata, A. (2013). Karahanl Türkçesinde İlk Kur'an Tercümesi (Rylands Nüshasl, Giriş-Metin-NotlarDizin). Ankara: Türk Dil Kurumu.

Ayverdi, İ. (2011). Astrlar boyu târihî seyri içinde Misalli Büyük Türkçe Sözlük (Redaksiyon-Etimoloji: Ahmet Topaloğlu). İstanbul: Kubbealtı.

Banarl, N. S. (1983). Resimli Türk Edebiyâtı Târihi I. İstanbul: Milli Eğitim Basımevi.

Bang, W., Gabain, A. von (1929). Türkische Turfan-Texte I. Berlin: Akademie der Wissenschaften.

Bardakcı, M. N. (2010). Türk Tasavvuf Kültüründe Gül Sembolü Üzerine Bazı Düşünceler. Bilal Kemikli, Selami Turan (Ed.), Gül Kitabı, Gül Kültürü Üzerine İncelemeler (s. 109-115), Isparta: Isparta Belediyesi Kültür ve Sosyal İşler Müdürlüğü.

Bayram, Y. (2001). Çiçekler ve Diğer Bitkilerin Dîvân Şïrine Yansımaları ile Anlam Çerçeveleri. (Yayımlanmamış Doktora Tezi). Samsun: Ondokuz Mayıs Üniversitesi Sosyal Bilimler Enstitüsü.

Baytop, T. (2007). Türkçe Bitki Adları Sözlüğü. Ankara: Türk Dil Kurumu.

Biltekin, H. (Haz.) (2018). Şeyhî Dîvânı. Ankara: Kültür ve Turizm Bakanlığı Kütüphaneler ve Yayımlar Genel Müdürlüğü.

Caferoğlu, A. (1930). Orhon Abidelerinde Atalarsözü. Halk Bilgisi Haberleri ( 1 (3), s. 43-46). İstanbul İktisat Matbaası.

Caferoğlu, A. (1931). Abû - Hayyân Kitâb al-İdrâk li-lisân al-Atrâk. İstanbul: Evkaf Matbaası.

Caferoğlu, A. (2011). Eski Uygur Türkçesi Sözlüğü. Ankara: Türk Dil Kurumu.

Cebecioğlu, E. (2004). Tasavvuf Terimleri ve Deyimleri Sözlüğü. İstanbul: Anka.

Clauson, G. (1972). An Etymological Dictionary of Pre-Thirteenth Century Turkish. London: Oxford University Press.

Deliorman Orhan, D., Ergun, F., Orhan N. (2011). Anadolu Medeniyetlerinde Asma (Vitis vinifera L.). Tarih Araştırmaları Dergisi, 30 (50), 69-80.

Ercilasun, A. B., Aliyev, A. M., Şayhulov, A., Kajıbek, E. Z., Konkobay Uulu, K., Yusuf, B., Göklenov, C., Mahpir, V. U., Çeçenov, A. (1991). Karşılaşttrmah Türk Lehçeleri Sözlüğü. Ankara: Kültür Bakanlığı.

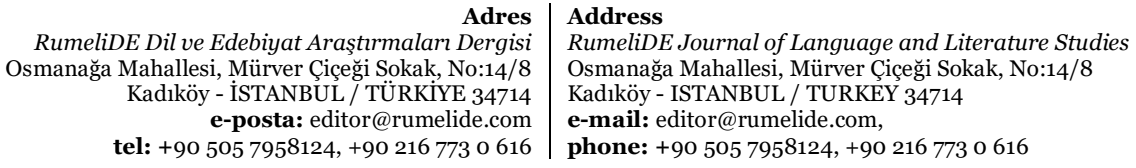


Ercilasun, A. B., Akkoyunlu, Z. (2015). Dîvânu Lugâtiłt-Türk Giriş-Metin-Çeviri-Notlar-Dizin. Ankara: Türk Dil Kurumu.

Erdağı Doğuer, B. (2018). Türkçede İki Alıntı Sözcük Ceviz ve Koz Üzerine. Turkish Studies, 13 (5), 147156.

Erdal, M. (1991). Old Turkic Word Formation A Functional Approach to the Lexicon I. Wiesbaden.

Erdal, M. (1993). Around the Turkic 'apple'. Journal of Indo-European Studies, 21, 27-36.

Eren, H. (1995). Türkçede Doublet Örnekleri. Türk Dili, 523, 731-736.

Eren, H. (1999). Türk Dilinin Etimolojik Sözlüğü. Ankara: Bizim Büro Basım Evi.

Eren, H. (2001). Türklerin Ana Yurdu Sorunu. Türk Dili, 600, 665-687.

Ergin, M. (2016). Dede Korkut Kitabı I-II. Ankara: Türk Dil Kurumu.

Ergun, P. (2004). Türk Kültüründe Ağaç Kültü. Ankara: Atatürk Kültür Merkezi Başkanlı̆̆ı.

Gülensoy, T. (2007). Türkiye Türkçesindeki Türkçe Sözcüklerin Köken Bilgisi Sözlüğü I. Ankara: Türk Dil Kurumu.

Günal, H. (2008). Türk Dünyasında İncir Kültürü. Turkish Studies, 3 (5), 561-581.

Hehn, V. (2003). Zeytin, Üzüm ve Íncir. (Çev. Necati Aça). Ankara: Dost Kitabevi.

İbrâhim Şinâsi, Ebüzziyâ Tevfik (H. 1302). Durûb-ı Emsâl-i Osmâniyye. İstanbul: Matbaa-i Ebüzziyâ.

İmer, Z. (2005). Miladi Dönem Öncesi Orta Asya'da İpek. Bilig, 32, 1-32.

İnan, A. (1986). Tarihte ve Bugün Şamanizm, Materyaller ve Araştırmalar. Ankara: Türk Tarih Kurumu.

Koçak, A. (2011). “Bilgelik” Varlık Bereket Sembolü İncirin Serüveni. Düzgün, D., Atnur, G., Güvenç, A. Ö., Yörük, Z. (Haz.), Bilge Seyidoğlu Kitabı (s. 277-289), İstanbul: Dergâh.

Kumova, U., Korkmaz, A., Avcı, B. C., Ceyran, G. (2002). Önemli Bir Arı Ürünü: Propolis. Uludă̆ Arıcılık Dergisi, 10-23.

Kurnaz, C. (1996). Gül. İslâm Ansiklopedisi (Cilt 14, s. 219-222). İstanbul: Türkiye Diyanet Vakfi.

Macit, M. (Haz.) (2017). Nedîm Dîvânı. Ankara: Kültür ve Turizm Bakanlı̆̆ı Kütüphaneler ve Yayımlar Genel Müdürlüğü.

Meninski, F. (1687). Complementum Thesauri Linguarum Orientalium, Seu Onomasticum LatinoTurcico-Arabico-Persicum. Vienna.

Ocak, A. Y. (2002). Alevî ve Bektaşî İnançlarını İslâm Öncesi Temelleri. İstanbul: İletişim.

Ögel, B. (1978). Türk Kültür Tarihine Giriş II. Ankara: Kültür Bakanlığı.

Ögel, B. (1995). Türk Mitolojisi II. Ankara: Türk Tarih Kurumu.

Pala, İ. (2002). Ansiklopedik Divan Şïri Sözlüğ̈̈. İstanbul: L M.

Pala, İ. (2020). İki Dirhem Bir Çekirdek. İstanbul: Kapı.

Püsküllüoğlu, A. (2012). Türk Atasözleri Sözlüğü. Ankara: Arkadaş Yayınevi.

Püsküllüoğlu, A. (2017). Türkçe Deyimler Sözlüğü. Ankara: Arkadaş Yayınevi.

Röhrborn, K. (1979-1998). Uigurisches Wörterbuch, Sprachmaterial der Vorislamischen Türkischen Texte Aus Zentralasien Lieferung 1-6. Wiesbaden.

Şen, M. (2006). Elma Kelimesi Üzerine. Büyük Türk Dili Kurultayı (s. 571-586). Ankara.

Şenocak, E. (2007). Türk Halk Kültüründe ve Mitolojik Bağlamda Üzümün Yeri. Milli Folklor, 19 (76), 164-172.

Şimşek, E. (2008). Ölümsüzlük İlâcı Elma. Turkish Studies, 3 (5), 193-204.

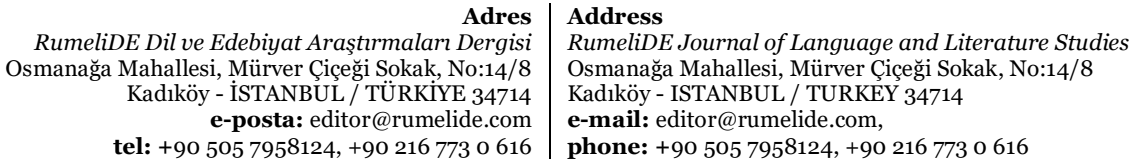


Şirin, H. (2015). Kül Tigin Yazıtı Notlar. İstanbul: Bilge Kültür Sanat.

Tatçı, M. (2009). Dervîşler Hümâ Kuşu Yûnus Emre Yorumları. İstanbul: H.

TDK (1941). Divânü Lûgat-it-Türk Tipkıbasımı. Ankara: Türk Dil Kurumu.

TDK (1993). Derleme Sözlüğü I-XII. Ankara: Ankara Üniversitesi Basımevi.

TDK (2019). Bölge Ağızlarında Atasözleri ve Deyimler. Ankara: Türk Dil Kurumu.

TDK (2019). Türkçe Sözlük. Ankara: Türk Dil Kurumu.

TDK Atasözleri ve Deyimler Sözlüğü. https://sozluk.gov.tr/.

Tekin, T. (2013). Irk Bitig Eski Uygurca Fal Kitabı. Ankara: Türk Dil Kurumu.

Toparl,, R., Vural, H., Karaatll, R. (2014). Kipçak Türkçesi Sözlüğü. Ankara: Türk Dil Kurumu.

Tulum, M. M., Azılı, K. (2015). Eski Uygurca Edgü Ögli Tigin Anyıg Ögli Tigin (İyi Niyetli Şehzade Kötü Niyetli Şehzade) Burkancl Seyirlik Eser. İstanbul: Doğu Kütüphanesi.

Ünsal, A. (2019). Ölmez Ağacın Peşinde, Türkiye’de Zeytin ve Zeytinyağı. İstanbul: Yapı Kredi.

Ünver, A. S. (1949). İçki Müptelâları Neden Yalancıktan Kuvvetli İnadcı, Geçici Hevesli ve Kindar Olurlar?. Türk Folklor Araşttrmaları, 1 (2), 17-18.

Veren, E. (2019). Kocakarı Soğuklarından Zemheriye Anadolu Halk Takvimi. İstanbul: Doğan Kitap.

Yıldırım, H. (2000). "Ayı Ü̈̈reğe” (Tanrı Öğretisi) Metni Esasında Saha Türkçesinde İsim. (Yayımlanmamış Yüksek Lisans Tezi). Ankara: Gazi Üniversitesi Sosyal Bilimler Enstitüsü.

Yund, K. (1944). Ağaç, Orman Üzerine Atasözleri ve Açılamaları. Ankara: Recep Ulusoğlu Basımevi.

Yurtbaşı, M. (2012). Sinıflandırılmış Türk Atasözleri. İstanbul: Excellence Dictionaries.

Yücer, H. M., Küçük, S. (2019). Tasavvuf Literatüründe Ağaç Sembolizmi ve Muhŷ̀nin Temsîl-i Şecer İsimli Eseri. Akademik Platform İslami Araşttrmalar Dergisi, 3 (1), 13-28.

https://www.tarimtv.gov.tr/tr/video-detay/zeytin-sinegi-zararlisina-incir-agacli-koruma-10489

https://www.tarim.com.tr/Ceviz-Agacinin-Altinda-Oturmak-Neden-Tehlikeli,39549h

RumeliDE Dil ve Edebiyat Araştırmaları Dergisi Osmanağa Mahallesi, Mürver Çiçeği Sokak, No:14/8 Kadıköy - İSTANBUL / TÜRKIYE 34714 e-posta: editor@rumelide.com tel: +90 $5057958124,+902167730616$
Address

RumeliDE Journal of Language and Literature Studies Osmanağa Mahallesi, Mürver Çiçeği Sokak, No:14/8

Kadıköy - ISTANBUL / TURKEY 34714

e-mail: editor@rumelide.com,

phone: +90 $5057958124,+902167730616$ 